\title{
体育教師の信念が経験と成長に及ぼす影響 : 「教師イメージ」と「仕事の信念」の構造と機能
}

\author{
朝倉 雅史 ${ }^{1)}$ 清水 紀宏 ${ }^{2)}$
}

Masashi Asakura ${ }^{1}$ and Norihiro Shimizu²: A study of how teachers' beliefs affect the experiences and professional development of physical education teachers: Composition and function of their image of what a teacher is and vocational beliefs. Japan J. Phys. Educ. Hlth. Sport Sci. 59: 29-51, June, 2014

\begin{abstract}
The professional development of a physical education (PE) teacher occurs within a variety of experiences that become resources for the teacher to learn from. However, to gain experience does not necessarily mean development. Development through learning by experience is influenced by the beliefs that the person has. The purpose of this study was to determine the composition and function of PE teacher beliefs — - especially "image of what a teacher is" and "vocational beliefs" that influence their professional development. In addition, we classified PE teachers by their beliefs, and examined their development status with a focus on the relevance of experiences for changing a teacher's ideals. A questionnaire survey was conducted. Data were collected from a sample of 634 junior high school and high school PE teachers. The main findings are summarized below.
\end{abstract}

1) Factor analysis of data revealed that the PE teachers' image of what a teacher is comprised 4 factors: "leader", "supervisor", "supporter of learning" and "team member", and vocational beliefs comprised 7 factors: "emphasizing public values", "self-actualization”, "pursuit of pioneering teaching practices", "emphasizing students", "professional exclusiveness", "exercise of autonomy" and "research orientation".

2) The teachers were classified by image of what a teacher is into 2 types: "supervisor" and "supporter". The teachers were classified by vocational beliefs into 5 types: "self-actualization", "emphasizing students", “open-minded beliefs", "self-righteous" and "close-minded beliefs". The ratios of young teachers classified into "supervisor" and "emphasizing students" were significantly larger than that of experienced teachers. The ratios of experienced teachers classified into "supporter", "self-actualization" and "self-righteous" were significantly larger than that of young teachers.

3) Factor analysis of data revealed that experiences comprised 5 factors: "reflecting on teaching practice", "knowledge acquisition", "conversing with fellow teachers", "observing and opening up one's own teaching practices" and "hard experiences". Experienced teachers were more passive in their experiences, except "knowledge acquisition", than younger teachers. For more experienced teachers, having positive experiences was more effective for changing ideals.

4) Teachers classified as the "open-minded beliefs" type were more willing to experience a variety of things than the "close-minded beliefs" type teachers. Regression analysis of data revealed that "emphasizing public values", "pursuit of pioneering teaching practices" and "research orientation" correlated significantly and positively with experience. But "professional exclusiveness", "exercise of autonomy" and years of service correlated significantly and negatively with experience.

\footnotetext{
1) 筑波大学大学院人間総合科学研究科 テ305-8574 茨城県つくば市天王台 1-1-1

2) 筑波大学体育系

干305-8574＼cjkstart茨城県つくば市天王台 1-1-1 連絡先 朝倉雅史
}

1. Graduate School of Comprehensive Human Sciences, University of Tsukuba 1-1-1 Tennodai, Tsukuba, Ibaraki 305-8574

2. Faculty of Health and Sports Sciences, University of Tsukuba

1-1-1 Tennodai, Tsukuba, Ibaraki 305-8574

Corresponding author dhsfpdhsfp@hotmail.co.jp 
Key words : teachers' learning, experiential learning, ability to learn from experience, teacher change, types of physical education teachers

キーワード : 教師の学習, 経験学習, 経験から学習する能力, 教師の変容, 体育教師のタイプ

\section{I．緒言}

\section{1. 問題}

学校の体育経営において高い経営成果を生久出 すために，保健体育教師(以下，体育教師と略す) の資質能力向上を図ることは人的資源マネジメン ト上の主要課題である。ただし，体育教師の資質 や能力は教師自身に帰属しており，それらを向上 させていくのもまた教師自身である。一航に, 複 雑性を有する教職の特性上，教師は日々の経験か ら学び教師として成長していく主体とみなされる (Armour, 2006 ; 坂本, 2007 ; 秋田, 2009). 故 に体育教師の資質能力の向上は，個々の体育教師 が経験から学び成長していく過程の中に見出され ることになろう。

そこで，体育教師はどのように成長していくの かが緊要の研究課題となる. だが, 体育教師の成 長については，近年になって成長過程を明らかに していく必要性が指摘されたばかりであり(木原, 2011)，とりわけ我が国の体育教師を対象とした 成長の実態やメカニズムの解明は端緒が開かれた 段階にある注1). 故に, 体育教師の成長過程やそ れを左右する要因に関する知見の不足はもとよ り，体育教師の成長をどのような視座から捉えて いくかについても共通理解が得られているとは言 い難い.

一方，一般的な教師の成長を過程的に検討して きた教師の自己形成史的研究では, 古くから研究 の蓄積が進められており, 経験を通じて生じるも のの見方・考え方の非連続的な変化が重視されて きた（稲垣ほか，1988；小山ほか，1990；グッ ドソン， 2001 ; 山㟝, 2002 ; グッドソン・サイ クス，2006)。このような視座は，成長する教師 の姿として，経験による学習加ら目指す教師像や 授業像を主体的に自己選択し，実践に対する考え が変容していくプロセスを想定している
(Guskey, 2002 ; 秋田, 2009, 山㟝, 2012, p. 163)。つまり，体育教師を含む一般的な教師の 成長は, 教師自らが経験を通じて学び，ものの見 方・考え方を選択し変容させていく過程と捉えら れる。

ところで，教師のみならずあらゆる専門職の成 長において，学習資源としての経験の重要性が指 摘されている. その意味で, 教師の成長を検討す るために蓄積されてきた自己形成史的研究は, 成 長の契機や転機に着目し，教師一般の成長に資す る出来事や経験について示唆に富む知見をもたら した (稲垣ほか, 1988 ; 小山ほか, 1990 ; 山㠃, 2002)．ただし，何が教師の成長に資する経験で あるかは重要な知見であるが，教師の成長を企図 した時，文脈的かつ複雑な教育実践の中で特定の 経験を意図的に生じさせることはもちろん，それ らを個々の教師に外部から計画的に付与すること は現実的に困難である.

成長にとっての経験の重要性は, ヒトが経験か ら学ぶという事実に基づき古くから注目されてき た．但し，経験が成長に繋がるのはそこに熟慮や 内省, 省察といったリフレクティブな行為が介在 することで学習が生起する場合である(デューイ, 1975 ; Kolb, 1984 ; ショーン, 2001). 即ち, 経験することが即, 成長に結びつくわけではな

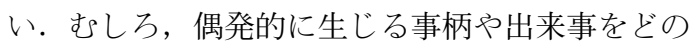
ように受け入れ，如何に成長に結び付けるかが現 場の教師にとっての発達課題といえる（岸野・無 藤，2006；梅野ほか，2010)。このことから, 経 験からの学習がいかなる要因によって促進される のかを解明することが，実践的意義を有する研究 課題となる.

経営学分野に抢いて人的資源マネジメントに最 も深く関わる人材育成研究の領域でも, 経営資源 としてのヒトを管理される対象としてではなく学 び成長する主体と捉え, 学習研究や熟達研究の知 見に依拠しつつ経験からの学習を規定している要 
因を「経験から学習する能力」として概念化し， 検討している(楠見, 1999 ; Moon, 2004 ; 松尾, $2006)$. 特に松尾 $(2006,2010,2012)$ は, 人間 の認知的活動や行動を方向づけるメタ認知として の「信念」に着目し, 経験から学習する能力の個 人差を実証している。信念に着目する有効性は, 経験から学習する能力としてそれまで明らかにさ れてきた態度や資質, スキル等の要因をより根底 から規定する点にある. 教師の成長に関する研究 と人材育成研究の展開は, ヒトを学び成長する主 体として捉える視座において共通するものの, 教 師を対象に経験から学習する能力を実証したもの はない。

認知科学的アプローチの台頭に伴って展開され た教師の意思決定や行為を対象とした研究によれ ば，個々の教師は，自らの経験を通じて形成して きた「個人レベルの指導論」（梶田，1986）や 「イメージ」(Elbaz, 1981), 「授業観」（浅田， 1998, p. 251）といった信念を有して抢り, 不確 実で複雑な教育実践に一定の方向性を見出し対処 していることがわかっている，このように個々の 教師が自分なりに描いている教師像や授業像等を 含む信念は, 経験を通じて形成された主観的な望 ましさを含意しており，知識のように客観的な正 しさを前提とはしない（Abelson，1979; Nesper, 1987; Pajares, 1992 ; 秋田, 2000). また, 目指 寸教師像や授業像が異なれば，その教師による行 為の選択もそこから得られる経験の意味も異なる (安藤, 2000 ; 山㟝, 2012, p. 160). したがっ て, 経験からの学習を通じて自己選択と変容がも たらされる教師の成長もこれらの信念によって規 定される，と考えることができる.

これまで，教師の信念概念は客観的な知識と対 比され注2)，授業場面に限らずなぜ教師がその様 に行為するかを包括的に説明し, 教師間の差異を 生み出している主観的認識を表す概念として扱わ れてきた（Nesper, 1987; Pajares, 1992 ; 黒羽, 1999 ; 藤木, 2000). また信念は, 理不尽な思い 込みのように強迫的で非合理的な「イラショナ ル・ビリーフ」(河村, 2000, p. 6) や「強固な信 念」（竹下，1996）をも含み, 偏ったものの見方
や考え方を導くことから「世界観を屈折させるレ ンズ」（レナード・スワップ，2005, p. 139）と も喻えられる, 故に, 信念は遭遇した多様な経験 に対する教師自身の解釈に際して, 肯定的な意味 づけのみならず否定的な意味づけをも導き，成長 の停滞にも影響を及ぼす.

体育教師についても，信念は彼らの成長を促進 あるいは阻害する重要な要因と考えられるもの の, 体育科という特定の教科を担当する教師を対 象として，彼らがどのような信念を保有してお り，それらが成長をどのように規定するかについ ては十分に検討されていない. 生徒指導や運動部 活動への傾倒, 自らのスポーツ経験の延長として 進行する職業的社会化, 体育科の周辺的な位置づ けといった体育教師に特徵的な指摘や報告（例え ば, 深沢·対馬, 1982 ; 杉本, 1989; Sparks et al., 1993 ; 山下. 徳永, 2000 ; 沢田, 2001など） からも, 体育教師の信念を固有の研究対象として 取り上げる意義が指摘できよう。ささらに信念が， 個人の有する人間観や仕事観として, 後天的に獲 得・形成されるものであるとすれば，体育教師の 信念を明らかにすることは, 優れた体育教師の養 成・研修方策の改善にとっても重要な課題である と考える.

\section{2. 先行研究の検討}

近年, 体育教師研究に抢いても, 一般の教育学 分野における認知科学的アプローチの展開に影響 を受ける形で, 教師の成長・発達に関わる心理的 要因が注目されてきた（Revegno，2003; Deglau and O'sullivan, 2006; Bechtel and O'sullivan, 2006). 欧米に扮ける体育教師の発達に関する研 究をレビューしたWang and Ha (2008)によれ ば, 発達に影響を与える個人的要因を検討した研 究の中では, 信念が最も多く取り上げられる要因 とされている．これに対して，わが国における体 育教師の信念に関する研究は発展の途上にあり (中井，2011），体系的な整理もなされていな い.ここでは体育教師の信念に関する先行研究を,

1) 信念と教師行動・指導スタイルの一貫性に関 する研究, 2) 信念の形成・変容過程に関する研 
究，3)信念と新たな経験や知識の獲得に関する 研究の 3 つに分類してレビューすることで，本 研究の具体的な課題を導出する.

まず，体育教師の信念と教師行動との関係につ いては，両者の間に関係が認められないことを実 証した研究（Kulinna et al., 2000）と両者の関係 性を事例的に実証した研究 (Bechtel and O'sullivan, 2007）が混在している．また，教師がぞの ような価值を志向するかが，具体的な行動だけで なく，教師のカリキュラム開発にも影響を与える とされ（Jewett and Bain, 1985)注3)，価值志向の 評価尺度（value orientation inventory: VOI）が 開発された（Ennis and Hooper，1988）。この尺 度得点を用いた調査研究により，体育教師の価值 志向の信念は，地域特性や社会的環境などの文脈 に制約されていることが明らかにされている (Ennis, 1992a, 1992b; Ha and Xu, 2002).

このように，信念が社会的要因に影響を受ける ことは，2つ目にあげた信念の形成・変容過程に 関する諸研究の中で指摘されている，例えば，教 員養成プログラムの教職志望者を対象とした事例 的研究により (Graber, 1995; Tsangaridou, 2008)，彼らの信念が社会的な相互作用によって 形成・変容していくことが明らかにされている. ただし，教師の信念形成には，一般的に被教育体 験期の経験も影響する（Nesper，1987)注4)。 た，体育教師の職業的社会化は，授業場面に限定 されない多様な場で展開されるスポーツ活動の影 響により，比較的早期に起こりうるため (Lawson, 1983 ; 朝倉・清水，2011）, 被教育体 験期から現在にいたる信念の形成要因を検討する 必要がある。このことに関連して朝倉・清水 （2010）は，体育教師の信念には自己にとって重 要性の高い「強い信念」とそうではない信念が存 在することを指摘し，実践を規定している「強い 信念」が，幼少期から現在に至るまでに遭遇した 社会的経験によって形成・強化されていることを 明らかにした。

最後に，信念と新たな経験や知識の獲得との関 係については, Ennis（1994）が，同様の知識を 有している体育教師でも実際の教育活動が異なっ
ており，知識の獲得と利用の仕方は，信念によっ て基礎づけられていると論じている，また厚東ほ か（2010）は，アメリカの Teaching Expertise 研究の文献的検討により，教師個人の有する知識 や技術から教授・学習過程や「出来事（class event)」が重視されるようになった趨勢を捉えた 上で，その出来事や経験から学ぶ力が教師の省察 とその省察に影響を及ぼす信念に支えられている ことを示唆している。これらの実証的研究として, Ennis et al. (1997) は VOI に基づいて体育教師を 分類し, 体育に関わる知識項目の結びつきを自己 評価させることで，教科の目的や学習者に関する 知識の構造（ネットワーク）が VOI の類型によ って異なることを実証した。 また, 朝倉・清水 （2012）は小学校教師を事例として，大学での長 期派遣研修によって体育授業観が変化し，今まで の授業経験をこれまでとは全く別の視点から解釈 するようになり，新たな知識を獲得していく過程 を描出している.

大きく 3 つに分類した以上の研究成果は, 信 念が実践の行動的側面と認識的側面を規定すると いう心理学的知見 (Rokeach, 1968, pp. 113-114; Fishbein and Ajzen, 1975, p. 15 ; レナード・スワ ップ，2005，pp. 175）を支持しているが，これ らの研究の多くは信念という概念を詳細に規定し ているわけではない，なお，信念概念は心理学に おける主要概念として扱われ，市る認知対象と他 の認知対象の連結によって形成されており，一般 的に複数の信念からなる信念体系を仮定している (西田，1998). 故に, 教師は多くの対象につい て信念を保有しているはずである。しかし，これ まで行われた教師の信念に関する研究では,この ような信念の内部構造を踏をえた概念規定と信念 の対象が検討されてきていない。このため，目指 す教師像がどのような信念から成り立っている か，また，何に対する信念が実践や経験の受け入 れを規定するかが明らかにされていない。さら に，一般に如何なる信念を保有する体育教師が存 在するのかといった基礎的知見も欠けている。 そ のため, 特に蓄積が進んでいる事例的研究におい て，事例のもつ特殊性や固有性，典型性などを明 
確に示すことも出来ていないのである注5).

\section{3. 目的}

本研究の目的は, 体育教師の成長を規定する要 因を解明し，彼らの資質能力向上に資する基礎的 知見を得るため, 体育教師の保有する信念の構造 と機能を明らかにし，体育教師の成長に打ける経 験と信念の関連を検討することである，そこで本 研究では, 心理学の知見に基づいて信念概念を規 定し, 体育教師の信念対象を選択・操作化した上 で 3 つの研究課題を設定した。第 1 に, 現職体 育教師の保有する信念の構造を実証し，どのよう な信念を保有する教師が存在するかを類型的に明 らかにする，第 2 に, 体育教師の成長に関わる ものの見方・考え方の変容と経験の受け入れ方の 実態及び両者の関連を明らかにする。第 3 に， 経験の受け入れ方に対してどのような信念が如何 なる影響を及ぼすかを明らかにすることである.

\section{II. 方法}

本研究は,「信念」を主要概念としてその構造 を検討すると共に，「体育教師の成長」と成長に とって重要な「経験の受け入れ」との関連を実証 した後,「経験の受け入れ」に対する「信念」の 機能を実証するものであり，主に，3つの概念を 分析の対象としている.

ここでは，まず信念概念を先駆的に究明してき た心理学の知見に基づいて詳細な概念規定を試み る. その後, 複数の対象をもつ信念の中から, 特 に教師の信念に関する実証的研究が進んでいる教 育心理学分野の知見および経験から学ぶ能力を実 証した人材育成研究の知見を踏をえ, 2 つ信念

「教師イメージ」と「仕事の信念」を抽出し, 操作化する.「経験の受け入れ」については, 成 長にとって意味ある経験を明らかにしてきた教師 の自己形成史的研究の知見に依拠して経験内容を 抽出した上で，その経験を如何に成長につなげる かという観点から「成長経験の受容」として操作 化する.「体育教師の成長」については, 教師の 主体的な成長を捉える視座と企業組織を主たる実
践領域とする人材育成研究における成長の捉え方 との異同を踏まえた上で, 経験からの学習を通じ た教師のものの見方・考え方の変容を捉えるため に体育授業の「理想像の変容」として操作化する. そして最後に，具体的な分析方法を提示する注6).

\section{1. 主要概念の検討 \\ (1) 信念概念の規定}

心理学に打ける信念は「ある対象と他の対象, 概念, あるいは属性との関係によって形成された 認知内容」（西田，1988）と規定されている. ま

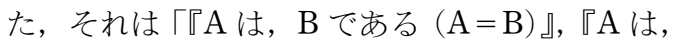
$\mathrm{B}$ ではない $(\mathrm{A} \neq \mathrm{B})$ 』」というように, 論理式で あらわされるものであることから「人間の記憶装 置の内部において，二つの認知を連結した命題の 形式によって形成された認知表象」（西田，1998, pp. 23-24）とも言われる. 信念研究の先駆であ る Rokeach（1968）は，信念を「『私は…と信じ る(思う)』という語句を前提に, 人の言葉や行 動から推測され，自覚されたりされなかったりす る簡潔な命題」(p. 113) と定義している.さら に, Fishbein and Ajzen (1975) によると信念は 「ある対象と他の対象, 価值, 概念, 属性などと の間に存在する関係についての主観的確率 (probability)」(p. 131) とされている.つまり, 行為者が 2 つ対象間に何らかの関係が存在す ると思っているかどうか，という「思い込み」 （信じている程度）を測る概念といえる.

な抢信念概念は, 多くの信念が体系化された信 念体系 (belief system) として存在するとされ， いくつかの信念体系モデルが提示されてきた (Rokeach, 1968; Green, 1971 ; 西田, 1988). そ れらによれば, 主に, 中心一周辺次元からなる球 体モデルが仮定され, 中心に位置づく信念ほど他 の信念との連結性及び重要度が高く, 変化に対し て抵抗し, あらゆる場面の意思決定に影響を及ぼ すとされる，また，信念間の連結性や重要度は， 自らの存在やアィデンティティに関わるほどより 強い（Rokeach, 1968, pp. 5-6; Abelson, 1986). なお, 連結性と重要度に基づく信念体系の強度 は, 質問紙における態度得点の高さによって操作 
化することが可能である（西田，1995）.

\section{(2) 体育教師が保有する信念の対象と操作化}

1）信念の対象

Calderhead（1996）は，信念のタイプやそれ らの質的な違いについてはあまり言及されてこな かったことを踏まえた上で，教師が主要な信念を 保持する 5 つの領域を提示している.すなわち， (1)学習者と学習についての信念, (2)指導について の信念, (3)教科についての信念, (4)指導すること に関する教師の学びについての信念，(5)指導にお ける自己の役割についての信念, である。 また，

Tsangaridou（2006）は，それまでの体育科教育 学研究を基に，体育教師が強い信念を抱いている ことを示唆する教育問題を10のカテゴリーに分 類している，すなわち，(1)体育の目的についての 教職志望者の信念, (2)指導についての学びと指導 経験についての信念, (3)効果的な指導についての 信念，(4)学級担任の体育指導についての信念，(5) 学習者と学習に対する信念, (6)信念と指導実践と の関係についての信念，77教材についての信念，

8自己および指導における自らの役割についての 信念，9仕事の本質についての信念，(10)教師の心 配事注7)である。

これらのカテゴリーは先行研究の知見を踏をえ て仮説的に提示されたものであり，相対的な重要 度が示されているわけではない，だが，前述の概 念規定を踏まえると，信念は自らのアイデンティ ティや存在に関わる信念ほど，あらゆる意思決定 に対して強い影響を及ぼす（Rokeach，1968，pp. 5-6; Abelson, 1986)。つまり，自分はどのような 教師か，自らが従事している体育教師とはどのよ うな役割を担う職業なのか，といった自己に直接 関わる信念ほど実践や経験の受け入れを左右する と考えられる. そこで, 本研究では以上のカテゴ リーを参考として，体育教師にとって自らのアイ デンティティや存在に直接関わると推論される 「自己打よび指導に抢ける自らの役割についての 信念」と体育教師という「仕事の本質についての 信念」に焦点化する注8)．そして，これらの信念 を詳細に検討するため，前者については教師の自 己に対する信念である「教師イメージ」, 後者に
ついては体育教師自らの仕事に対する信念である 「仕事の信念」として操作化を試みることとした.

2）自己に対する信念の操作化一一体育教師 の「教師イメージ」尺度

自己に対する信念を捉えるために導入する教師 のイメージについては，1980年代以降，教師の 主体性や自律性を強調する教師観の提起ととも に, 教師の多様な知識から成り立つ実践的知識へ の着目を契機として研究が進められてきた(深見, 2006). とりわけ，実践的知識の構成要素注9)の 1 つとしてイメージを取り上げた Elbaz（1981）に より「教師の感覚, 価值, 要求, 信念が結合し, ぞのように指導すべきかが簡潔な比喻的命題とし て定式化されたもの」(p. 61) と定義されて以降, イメージは教師の認識枠組みを明らかにする上で 有効な概念とされている.

なお，信念は必ずしも明示的・自覚的な命題と して表出されるわけではなく, 教師は言明化する ことの難しい信念をも保有している．その点で, 比喻的命題（メタファー）として表されるイメー ジは，教師の信念を拡張的・包括的に捉えること が出来る、また，イメージは教師による授業の実 践や観察等さまざまな行為に影響を与える点で信 念と共通しており (Calderhead, 1996), 信念研 究をレビューした Pajares (1992) もまた，イメー ジは教師の信念を説明する手がかりになると述べ ている。

教師の成長という観点からも, 教師の信念を検 討するために比喻生成課題を用いて教師の保有す るイメージを調査した秋田（1996）の研究以降, イメージの変容が教師の授業観や教師観の変容を 示唆すると共に, 初任者から熟達者へ至る道筋を 明らかにする上で有効であることが報告されてい る（深見， 2007 ; 三島，2008など）。なお，教師 のイメージ研究では, 主に「子ども」「授業」「教 師」についてのイメージが抽出されてきた。本研 究では，イメージが信念を操作化する上で有効な 概念であること，信念のうち自らの存在に直接関 わる信念が最もヒトの認識や行為を規定すること

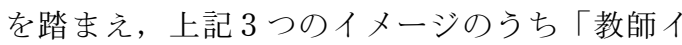
メージ」(授業に抢ける教師の役割に関するイメー 
ジ）を取り上げる。

なお，イメージに関する研究では，授業や教師 のイメージに関するメタファー項目（「…，… のようだ」）が使用されている。このようなメタ ファーは, 教師の信念を明らかにし, 探究するた めの有用な手がかりであり，その変容は信念や実 践の変容の前兆となることが指摘されている (Bullough and Baughman, 1997). そこで本研究 では，秋田（1996）を参考に，体育教師が保有 する教師イメージとして16のメタファー項目を 設定した。な招，測定尺度は，「7：全くその通 りである」から「1：全くそうではない」のリッ カート型尺度からなる 7 段階評定法を用いた。

3）仕事に対する信念の操作化一一体育教師 の「仕事の信念」尺度

「仕事の信念」については, 経営学分野の人材 育成研究領域において, 経験学習論に依拠しなが ら熟達プロセスを検討した松尾（2006, pp. 125$152 ）$ が，営業担当者の「仕事の信念」である 「目標達成志向の信念」と「顧客志向の信念」に よって, 経験からの学習が促されることを実証し ている.さらに, 経験から学習する能力の 1 つ として「メタ知識（metacognitive knowledge）」 を挙げ，職業人が持つメタ知識は，「仕事観」や 「仕事の信念」として，個別の知識獲得や活動に 大きな影響を与えることも明らかにしている（松 尾, 2010).

教師を対象とした研究に抢いても，信念が新た な知識や経験の受け入れ方を規定することについ ては言及されており，例えば，教師に提示された ある知識が，その教師の保持している信念体系と 調和しない場合は，新たな知識や経験に対する否 定や抵抗が起こり, 既存の知識構造や実践に変化 は生じないとされている（Pajares，1992; Ennis， 1994)。だが，何に対する信念が規定因となり得 るかについての実証的知見はほとんどない。そこ で本研究では, 体育教師の「経験から学習する能 力」を実証することを主眼に置き，体育教師自身 のアイデンティティが反映されたメタ知識にあた る，体育教師の「仕事の信念」を取り上げその構 造と機能を検討していくこととした.
なお，体育教師が保有する仕事の信念について は，体育教師の仕事観に関する研究が未だ報告さ れていないことから，田尾（1983）を参考に質 問項目を作成した. 田尾（1983）は, 複数の専 門職を対象に自らの職に対する態度を比較分析し ている。この尺度は，Hall（1968）による理論 的枠組みを踏まえ, Snizek（1972）が作成した 尺度を基に, 日本における様々な専門職の態度構 造を検討するため開発されたものである注10)。な 抢，松尾（2006, p. 182）が明らかにした「仕事 の信念」も，プロフェッショナリズムの特性を反 映したものであったことが報告されている．そこ で本研究では，田尾（1980，1983）の尺度を修 正し，体育教師の職務に適した項目を加え，仕事 の信念をたずねる40項目を設定した注11)。測定は 体育教師という仕事のあり方に関する項目に $\lceil 7$ : 全くその通りである」から「1：全くそうで はない」のリッカート型尺度からなる 7 段階評 定法で回答を求めた.

\section{2. 体育教師による経験の受け入れと成長の操 作化}

（1）体育教師の「成長経験の受容」尺度

本研究は, 体育教師の成長に抢ける経験の重要 性を認めながらも, 経験することが即, 成長に結 びつくわけではなく, 遭遇した経験を如何に受け 入れるか，その受け入れに信念がぞう関係するか を基本的な問題関心としている. 教師の成長にと って意味ある経験については, 教師の成長契機や 転機に着目した研究（稲垣ほか，1988; 小山ほ か，1990，1994；山㟝，2002）が，順位法を用 いてその経験内容を明らかにしている. 一方，岸 野・無藤（2006）は教師が直面した多様な出来 事を自分の課題に引き付けて捉え, 積極的な意味 付けを行うことが専門性を向上させることを明ら かにしている. 本研究もまた，どのような経験を するかのみならず，成長契機となり得る経験を如 何に積極的に受け入れるかを問題とするため，体 育教師による経験とその受け入れを「成長経験の 受容」として操作化した.

まず，教師の成長に関わる経験について稲垣ほ 
か $(1988)$ ，小山ほか $(1990,1994)$ ，山㠃 （2002）が明らかにした教師の成長契機や転機を 参考にして，一般的な成長経験を項目化した。 の上で，積極的な経験の受容を捉えるため，体育 教師としての成長にとってそれらの経験をどの程 度重要と考えるかを測定する評定法を用いた。具 体的には26の経験項目を設定し，「5：極めて重 要である」から「1：あまり重要ではない」のリ ッカート型尺度による 5 段階評定法を用いた。

\section{（2）体育授業の「理想像の変容」}

本研究では, 体育教師の成長を検討する上で人 材育成研究における枠組みを援用するが，人材育 成研究が対象とする実践領域は主に企業組織であ り，ヒトの成長は主として業績（売上や契約数） などの指標を用いて操作化される，一方，教師の 成長は，教職の複雑性や不確実性あるいは文脈性 からして，標準化された指標を用いて操作化する ことの難しい概念である。故に，これまで蓄積さ れてきた教師の成長に関する研究では, 経験によ る学習から目指寸教師像や授業像を主体的に自己 選択し，実践に対する考えが変容していく主観的 なプロセスが重視されてきた（Guskey，2002； 秋田, 2009, 山㠃, 2012, p. 163).

そこで本研究では，教師の成長を捉える指標と して，客観的な指標を用いるのではなく，入職時 と比べ授業の理想像がどの程度変容したかを教師 自身の自己評価によって測定することとした，具 体的な尺度としては「1. 入職時とほとんど変わ っていない」「2. 入職時とは，多少変わった」「3. 入職時とはかなり変わった」「4. 入職時とは, 大 きく変わった」からなる名義尺度を用いて，その 回答から群分けを行った。すなわち， 1 または 2 に回答した者を「非変容群」，3 または 4 に回答 した者を「変容群」とした。

\section{3. 調査および分析の方法}

\section{(1) 調査方法}

2011年 3 月から 4 月にかけて, 全国から無作 為に抽出した公立中学校および高等学校の保健体 育科教員を対象に，郵送自記式の質問紙調査を実 施した．対象サンプル数は 2000 ，回収数668（回
収率： $33.4 \%$ )，分析に用いた有効サンプル数は 634であった。

\section{(2) 分析方法}

収集されたデータの分析は, 本研究の 3 つの 研究課題に沿い, 以下の手順で進めた。

分析 1 :「教師イメージ」と「仕事の信念」の 構造を捉えるため，それぞれの尺度に対して探索 的因子分析（主因子法，Varimax 回転）を行っ た. 因子数の決定については固有值 1 以上の基 準を設け，因子負荷量が 0.4 に満たない項目を除 外して，再度因子分析を行った。 その後, 保有す る信念のタイプによって体育教師を類型的に把握 するため, 因子得点をもとに階層的クラスター分 析 (Ward 法，平方ユークリッド距離）を行った. クラスター数の決定は, デンドログラムと距離行 列の検討およびクラスターごとの分散分析結果か ら，解釈可能性を考慮して決定した。さらに， 「経験年数グループ」(3 群)注12),「理想像の変容」 ごとにみた各クラスターの比率，打よび $2 つ 0$ 信念クラスター間の比率をクロス集計表（ $\chi^{2}$ 検 定）によって分析した.

分析 $2: 「$ 成長経験の受容」に対して探索的因 子分析（主因子法，Promax 回転）を行った。因 子数の決定については, 固有值 1 以上の基準を 設け，因子負荷量が $0.4 に$ 満たない項目を除外し て分析を行った．その後，下位尺度得点として因 子得点を求めた. さらに, 経験年数の蓄積と「成 長経験の受容」の関係から経験の受け入れ方の実 態を分析するため，「成長経験の受容」を従属変 数,「経験年数グループ」を独立変数とする分散 分析を行った。さらに，「成長経験の受容」と 「理想像の変容」の関連を検証するため, 経験年 数グループ別に「理想像の変容」の有無による $「$ 成長経験の受容」の比較分析（ $t$ 検定）を行っ た注13).

分析 3 : 仕事の信念と経験の受け入れの関連を 分析するため,「成長経験の受容」を従属变数, 「仕事の信念」クラスターを独立变数とする分散 分析を行った。 その後，体育教師が保有する信念 の機能を詳細に検討するため，「成長経験の受容」 を従属変数，「仕事の信念」と「教職経験年数」 
を独立変数とする重回帰分析を行い，成長経験の 受容に対する各变数の相対的な影響力を分析した.

\section{III. 結果}

1. 体育教師が保有する信念の構造（分析 1）

（1） 体育教師が保有する信念の因子構造

1）「教師イメージ」の因子構造

「教師イメージ」に対する因子分析を行った結 果，4 因子（累積寄与率：51.04\%）が抽出され た（表 1).

第 I 因子は, 生徒を学習へと向かわせ, 学習成 果の獲得へと導いていくイメージとして解釈され ることから「誘導者」と命名した，第因子は， 教師を生徒よりも上位に位置している存在として イメージする因子と解釈されることから「管理者」 と命名した，第而因子は，生徒間あるいは生徒と 学習内容の間に立ち, 学習を促進するイメージと
解釈されるため「学習支援者」と命名した。第 $\mathbb{N}$ 因子は，生徒の学習を支えるために協力する存在 として解釈されるため「協力者」と命名した.

2）「仕事の信念」の因子構造

「仕事の信念」に対する因子分析を行った結果, 7 因子（累積寄与率：46.28\%) 注14) が抽出された (表 2).

第 I 因子は，体育教師が担う職務の文化的・社 会的な意義に関わる項目に高い負荷量を示してお り，仕事に関わる公共的な価值を志向する信念と 解釈されるため「公共的価值の重視」と命名した. 第II因子は，体育教師としての仕事を自らの能力 や潜在的な可能性を活かす職として捉えていると 解釈される，さらに，田尾（1983）で抽出され た因子との対応から「職務における自己実現」と 命名した，第正因子は，体育教師としての良質な 仕事を行う上で，新たな実践を教師集団と共に展 開していくことを重視しつつ，人間としてのロー

表 1 教師イメージの因子分析結果

\begin{tabular}{|c|c|c|c|c|c|c|c|}
\hline & $\mathrm{I}$ & II & III & $\mathrm{N}$ & 共通性 & $M$ & S.D. \\
\hline \multicolumn{8}{|l|}{ I 誘導者 $(\alpha=.809)$} \\
\hline 生徒に学習への興味を湧かせるように語りかける話し手 & .720 & .142 & .257 & .244 & .664 & 5.18 & 1.13 \\
\hline 技のポイントや練習の仕方をわかりやすく教えるコーチ & .661 & .260 & .230 & .059 & .561 & 5.38 & 1.04 \\
\hline 授業を綿密に計画し，それを生徒に指示するプランナー & .612 & .266 & .172 & .184 & .509 & 4.78 & 1.20 \\
\hline 生徒とともに授業をつくる共同制作者 & .483 & .053 & .118 & .353 & .374 & 4.96 & 1.21 \\
\hline 生徒を一定の目的の方向に導くガイド & .462 & .306 & .282 & .179 & .418 & 5.01 & 1.14 \\
\hline \multicolumn{8}{|l|}{ II＼cjkstart管理者 $(\alpha=.761)$} \\
\hline 生徒の学習からの逸脱を防止する監視者 & .169 & .645 & .087 & .174 & .483 & 4.15 & 1.45 \\
\hline 学習の規律を保ち, クラスの雾囲気を引き締める権威者 & .181 & .622 & .227 & .090 & .479 & 5.08 & 1.33 \\
\hline 生徒に手本を示す運動万能な競技者 & .109 & .600 & .130 & .254 & .454 & 4.33 & 1.29 \\
\hline 運動のことならば何でも知っている有識者 & .310 & .578 & .195 & .137 & .486 & 4.72 & 1.26 \\
\hline 授業をとり仕切る独裁者 & .068 & .477 & -.067 & .014 & .237 & 2.59 & 1.41 \\
\hline \multicolumn{8}{|l|}{ III＼cjkstart学習支援者（ $\alpha=.795 ）$} \\
\hline 生徒の意見や発想の引き出し役 & .208 & .043 & .813 & .234 & .760 & 5.53 & .97 \\
\hline 子どもに必要なヒントを与えるアドバイザー & .249 & .062 & .769 & .182 & .689 & 5.66 & .98 \\
\hline 運動に関する知識や技術の伝達者 & .276 & .303 & .510 & -.007 & .428 & 5.70 & 1.00 \\
\hline \multicolumn{8}{|l|}{$\mathbb{N}$ 協力者 $(\alpha=.698)$} \\
\hline 生徒ともに運動学習を楽しむパートナー & .279 & .216 & .127 & .671 & .591 & 4.81 & 1.29 \\
\hline 生徒の悩みや疑問を丁寧に聞くカウンセラー & .220 & .275 & .277 & .566 & .521 & 4.77 & 1.23 \\
\hline 因子寄与 & 2.26 & 2.20 & 1.96 & 1.23 & 6.42 & & \\
\hline 寄与率 & 15.05 & 14.66 & 13.09 & 8.23 & 51.04 & & \\
\hline
\end{tabular}

†主因子法, バリマックス回転による. 因子負荷 0.4 以上を太字で表記. 
表 2 仕事の信念の因子分析結果

\begin{tabular}{|c|c|c|c|c|c|c|c|c|c|c|}
\hline & I & II & III & $\mathrm{N}$ & $\mathrm{V}$ & $\mathrm{VI}$ & VII & 共通性 & $M$ & S.D. \\
\hline \multicolumn{11}{|l|}{ I. 公共的価值の重視 $(\alpha=.754)$} \\
\hline 私の仕事は, 文化の創造·発展を図る仕事である & .579 & .070 & .294 & .043 & .020 & -.037 & .166 & .458 & 4.77 & 1.09 \\
\hline 私の仕事は, 文化の伝達・継承を図る仕事である & .578 & .120 & .103 & .010 & -.018 & .033 & .150 & .383 & 4.96 & 1.01 \\
\hline 私の仕事は，社会に大きな貢献をしている & .567 & .161 & .078 & .237 & .125 & -.133 & .127 & .459 & 5.45 & 1.05 \\
\hline 私の仕事は，社会に欠くことはできない & .534 & .235 & .177 & .126 & .016 & -.144 & .020 & .409 & 5.76 & 1.15 \\
\hline \multicolumn{11}{|l|}{ II. 職務に打ける自己実現 $(\alpha=.695)$} \\
\hline この仕事は私の才能をいかすのに最も適している & .180 & .635 & .026 & .229 & .201 & -.026 & .052 & .533 & 5.10 & 1.19 \\
\hline 私には, 保健体育教師としての生涯を貫くようなライフワークがある & .261 & .627 & .082 & .151 & .061 & .038 & .257 & .562 & 4.88 & 1.41 \\
\hline たとえ今後, 収入が減るとしてもこの仕事を続けたい & .090 & .524 & .093 & .080 & .051 & -.088 & .119 & .322 & 5.70 & 1.32 \\
\hline \multicolumn{11}{|l|}{ III. 先導的実践の追求 $(\alpha=.652)$} \\
\hline 私の仕事は，常に新しい試みを取り大れて取り組まなければならない & .073 & .111 & .695 & .023 & -.014 & -.032 & .105 & .514 & 5.36 & 1.00 \\
\hline たえず新しい知識や技術を学ばなければよい仕事はできない & .142 & .110 & .496 & .116 & -.058 & -.162 & .139 & .341 & 5.83 & 1.05 \\
\hline 私の仕事では，同僚と歩調を合わせることが求められる & .206 & -.038 & .452 & .105 & -.015 & -.012 & .006 & .260 & 5.57 & 0.98 \\
\hline 私の仕事には，倫理観や道德心が特に求められる & .376 & .095 & .409 & .146 & .083 & -.185 & .001 & .380 & 5.84 & 0.95 \\
\hline \multicolumn{11}{|l|}{ N. 生徒重視 $(\alpha=.782)$} \\
\hline 生徒の願いや要求に応えるため最善の努力をしている & .165 & .204 & .113 & .761 & .086 & -.001 & .172 & .698 & 5.54 & 0.94 \\
\hline 生徒に学び, 生徒と共に成長するように心か゚けている & .138 & .241 & .225 & .681 & -.009 & -.176 & .113 & .636 & 5.85 & 0.98 \\
\hline \multicolumn{11}{|l|}{ V. 自律性の行使 $(\alpha=.748)$} \\
\hline 仕事上のことは，すべて私自身の判断で決めている & .031 & .073 & -.020 & .028 & .821 & .199 & .095 & .730 & 3.94 & 1.33 \\
\hline 仕事の上で困難なことが起こっても私自身で解決する & .053 & .146 & -.027 & .045 & .683 & .063 & .072 & .502 & 4.30 & 1.34 \\
\hline \multicolumn{11}{|l|}{ V. 専門的閉鎖性 $(\alpha=.607)$} \\
\hline 私の仕事が良いか悪いかは，同じ仕事をしている人だけにわかることである & -.054 & -.068 & -.063 & -.055 & .079 & .789 & -.009 & .644 & 2.91 & 1.43 \\
\hline 仕事の内容をよく知らない人から意見や指示を受けることはない & -.091 & -.016 & -.111 & -.053 & .137 & .507 & -.013 & .299 & 3.37 & 1.37 \\
\hline \multicolumn{11}{|l|}{ UI. 研究志向 $(\alpha=.570)$} \\
\hline 私は, 仕事に関する専門誌を定期的に読んでいる & .136 & .216 & .040 & .059 & -.022 & -.072 & .620 & .461 & 4.05 & 1.79 \\
\hline 私の仕事に関係のある学会や研究会に欠かさず出席している & .076 & .033 & .072 & .071 & .123 & .059 & .480 & .266 & 2.94 & 1.39 \\
\hline 自分から進んで授業についての良質な知識・情報を求めて行動している & .211 & .212 & .221 & .240 & .096 & -.101 & .429 & .399 & 5.03 & 1.11 \\
\hline 因子寄与 & 1.72 & 1.43 & 1.39 & 1.32 & 1.27 & 1.09 & 1.04 & 9.26 & & \\
\hline 寄与率 & 8.62 & 7.16 & 6.94 & 6.60 & 6.36 & 5.43 & 5.18 & 46.28 & & \\
\hline
\end{tabular}

†主因子法, バリマックス回転による. 因子負荷 0.4 以上を太字で表記.

ルモデルとなることを示唆する信念と解釈される ため「先導的実践の追求」と命名した. 第 $\mathbb{N}$ 因子 は，仕事において生徒を重視する信念に関する項 目に高い負荷量を示して抢り，また，先行研究の 「クライエント重視」（田尾，1983）と対応する ため「生徒重視」と命名した。第 V因子は，意思 決定主体を自分自身とみなす項目であり，専門職 の職務に打ける責任の所在や職務の遂行に関わる 「自律性の行使」（田尾，1983）と対応するため 「自律性の行使」と命名した。第V因子は，職務 の専門性から生まれる閉鎖性に対する信念と解釈 されるため「専門的閉鎖性」と命名した．第UI因 子は, 体育教師の仕事に関する知識や情報を積極 的に入手することに関する信念と解釈され，ま た, 田尾（1983）の結果との対応から「研究志 向」と命名した。
(2) 体育教師の信念クラスター

1)「教師イメージ」クラスター

「教師イメージ」の因子得点をもとにクラスター 分析を行った結果, 解釈可能な 2 つクラス ターを抽出した．2つのクラスターにおける各因 子得点平均の比較分析の結果 (表 3 ), 両クラス ター共に「誘導者」の得点に有意な差はなく, 「学習支援者」の得点が有意に高いクラスターと, 「管理者」抢よび「協力者」の得点が有意に高い クラスターに分類できた.

前者は生徒と学習の間に立ち, 生徒を主体とし た学習を促進することを重視していることから 「支援者型」(52.2\% : 括弧内はクラスターサイ ズ, 以下同様), 後者は生徒を管理しつつ, 時に は競技者や有識者あるいは協力者として生徒を学 習へと牽引する存在と解釈し「管理者型」(47.8 
\%) とした.なお，クラスターサイズに大きな偏 りは見られなかった。

2)「仕事の信念」クラスター

同様に「仕事の信念」の因子得点を基にクラス ター分析を行った結果, 解釈可能な 5 つのクラ スターを抽出した (表 4). 分散分析の結果, 全 ての因子に拈いてクラスターによる $0.1 \%$ 水準の 有意な差がみられた，以下では，サイズの大きな クラスターから解釈していく.

第 1 クラスターは，「職務における自己実現」 の值が高い点に特徵があり，「自律性の行使」お よび「専門的閉鎖性」の值も高い.このクラスター に抢ける自律性や閉鎖性に対する志向の強さは, 自己実現を重要視する信念の強さに伴っていると 解釈されるため「自己実現型」(24.4\%) とした.

第 2 クラスターは,「生徒重視」の值が最も高 く,「自律性の行使」と「公共的価値の重視」の 值が低いという特徵を有しており, 体育教師とし ての仕事に打いて目の前に存在する生徒を重視す る信念を持つクラスターと考えられるため「生徒 重視型」(24.3\%) とした.

表 3 教師イメージクラスターの比較分析結果 ( $t$ 検定 $)$

\begin{tabular}{lcrrr}
\hline & $\begin{array}{c}\text { C1 支援者型 } \\
(\mathrm{n}=325: 52.2 \%)\end{array}$ & $\begin{array}{c}\mathrm{C} 2 \text { 管理者型 } \\
(\mathrm{n}=298: 47.8 \%)\end{array}$ & $t$ 值 \\
\hline $\mathrm{I}$ 誘導者 & $.042(1.001)$ & $-.045(.631)$ & 1.31 \\
$\mathrm{II}$ 管理者 & $-.149(.961)$ & $.162(.685)$ & $-4.68^{* * *}$ \\
$\mathrm{III}$ 学習支援者 & $.582(.623)$ & $-.634(.677)$ & $23.34^{* * *}$ \\
$\mathrm{~N}$ 協力者 & $-.106(.867)$ & $.115(.642)$ & $-3.64^{* * *}$ \\
\hline & & & & $* * * p<.001$
\end{tabular}

第 3 クラスターは,「専門的閉鎖性」と「自律 性の行使」の両方の值が低いという特徵があり, 他の信念については值が高い. 特に, 公共的な価 値や生徒の重視, 先導的な実践の追求と関連する 研究志向の高さなどは, 自らの信念と相反するよ うな新たな情報に対する寛容性を窥わせるもので あり，「開かれた心」（Rokeach，1960）を示唆 していることから「開放的信念型」(21.9\%) と した。

第 4 クラスターは,「自律性の行使」の值が高 く,「研究志向」「職務に打ける自己実現」の值が 最も低い. 同じく「自律性の行使」の值が高い 「自己実現型」（第 1 クラスター）に比べると, 体育教師の仕事において自らの判断に基づいて意 思決定すること自体を強く志向していると解釈さ れるため，「独善型」（15.9\%）とした.

第 5 クラスターは,「専門的閉鎖性」の值が最 も高い点に特徽がある．ただし「自律性の行使」 の值が最も低いことから，自律的な意思決定を重 視しているわけではない。ささらに，「公共的価值 の重視」や「職務に打ける自己実現」の值も低く, このクラスターは体育教師という職業の中で, 淡 々と職務を遂行していくといった閉ざされた信念 を特徵とするクラスターと考えられる.よって 「閉鎖的信念型」(13.4\%) とした.

\section{(3) 体育教師の信念クラスターにみられる一般 的傾向 (表 5 参照)}

1）「教師イメージ」クラスターの一般的傾向 まず，「経験年数グループ」ごとにみた「教師 イメージ」クラスターの比率について分析を行っ た結果（5-1），5\%水準で有意な差が認められ，

表 4 仕事の信念クラスターの分散分析結果

\begin{tabular}{|c|c|c|c|c|c|c|}
\hline & $\begin{array}{c}\mathrm{C} 1 \text { 自己実現型 } \\
(\mathrm{n}=155: 24.4 \%)\end{array}$ & $\begin{array}{c}\mathrm{C} 2 \text { 生徒重視型 } \\
(\mathrm{n}=154: 24.3 \%)\end{array}$ & $\begin{array}{l}\mathrm{C} 3 \text { 開放的信念型 } \\
(\mathrm{n}=139: 2.9 \%)\end{array}$ & $\begin{array}{c}\text { C4 独善型 } \\
(\mathrm{n}=101: 15 \%)\end{array}$ & $\begin{array}{l}\text { C5 閉銷的信念型 } \\
(\mathrm{n}=85: 13.4 \%)\end{array}$ & $F$ 値 \\
\hline I 公共的価值の重視 & $-.039(.567)$ & $-.337(.909)$ & $.468(.709)$ & $.212(.824)$ & $-.335(.595)$ & $28.57^{* * *}$ \\
\hline II 職務に抢ける自己実現 & $.304(.592)$ & $.120(.675)$ & $.375(.547)$ & $-.715(.872)$ & $-.536(.687)$ & $62.83^{* * *}$ \\
\hline III 先導的実践の追求 & $-.403(.721)$ & $-.019(.705)$ & $.693(.617)$ & $-.058(.735)$ & $-.295(.647)$ & $52.64^{* * *}$ \\
\hline N 生徒重視 & $-.069(.758)$ & $.351(.745)$ & $.324(.657)$ & $-.461(.916)$ & $-.491(.822)$ & $32.08^{* * *}$ \\
\hline $\mathrm{V}$ 自律性の行使 & $.532(.604)$ & $-.697(.749)$ & $.299(.634)$ & $.449(.646)$ & $-.728(.710)$ & $109.80^{* * *}$ \\
\hline VI 専門的閉鎖性 & $.513(.712)$ & $-.489(.573)$ & $-.162(.878)$ & $-.330(.599)$ & $.607(.652)$ & $63.48^{* * *}$ \\
\hline VII 研究志向 & $.130(.694)$ & $-.153(.677)$ & $.417(.646)$ & $-.565(.644)$ & $.030(.680)$ & $34.94^{* * *}$ \\
\hline
\end{tabular}


表 5 信念クラスターのクロス表

5-1＼cjkstart経験年数グループと教師イメージクラスター

\begin{tabular}{|c|c|c|c|c|}
\hline \multirow{2}{*}{ 経験年数グループ } & \multicolumn{2}{|c|}{ 支援者型 } & \multicolumn{2}{|c|}{ 管理者型 } \\
\hline & $\%$ & $\mathrm{n}$ & $\%$ & $\mathrm{n}$ \\
\hline 10 年未満 & 46.7 & (91) & 53.3 & (104) \\
\hline 10 年以上 20 年未満 & 60.0 & (93) & 40.0 & $(62)$ \\
\hline 20 年以上 & 51.6 & (141) & 48.4 & (132) \\
\hline 合計 & 52.2 & (325) & 47.8 & (298) \\
\hline
\end{tabular}

5-2＼cjkstart理想像の変容と教師イメージクラスター

\begin{tabular}{cccccc}
\hline \multirow{2}{*}{ 理想像の変容 } & \multicolumn{2}{c}{ 支援者型 } & & \multicolumn{2}{c}{ 管理者型 } \\
& $\%$ & $\mathrm{n}$ & & $\%$ & $\mathrm{n}$ \\
\hline 有り & 61.2 & $(170)$ & 38.8 & $(108)$ \\
無し & 44.9 & $(155)$ & 55.1 & $(190)$ \\
\hline 合計 & 52.2 & $(325)$ & 47.8 & $(298)$ \\
\hline & \multicolumn{3}{c}{$\chi^{2}=16.238$} & $p<.001$
\end{tabular}

5-3 経験年数グループと仕事の信念クラスター

\begin{tabular}{|c|c|c|c|c|c|c|c|c|c|c|}
\hline \multirow{2}{*}{ 経験年数グループ } & \multicolumn{2}{|c|}{ 自己実現型 } & \multicolumn{2}{|c|}{ 生徒重視型 } & \multicolumn{2}{|c|}{ 開放的信念型 } & \multicolumn{2}{|c|}{ 独善型 } & \multicolumn{2}{|c|}{ 閉鎖的信念型 } \\
\hline & $\%$ & $\mathrm{n}$ & $\%$ & $\mathrm{n}$ & $\%$ & $\mathrm{n}$ & $\%$ & $\mathrm{n}$ & $\%$ & $\mathrm{n}$ \\
\hline 10年未満 & 11.6 & (23) & 41.7 & (83) & 22.1 & (44) & 8.5 & (17) & 16.1 & $(32)$ \\
\hline 10 年以上 20 年未満 & 22.8 & (36) & 22.8 & $(36)$ & 24.1 & (38) & 19.6 & (31) & 10.8 & (17) \\
\hline 20 年以上 & 34.7 & (96) & 12.6 & (35) & 20.6 & (57) & 19.1 & (53) & 13.0 & (36) \\
\hline 計 & 24.4 & $(155)$ & 24.3 & $(154)$ & 21.9 & (139) & 15.9 & $(101)$ & 13.4 & (85) \\
\hline
\end{tabular}

5-4 教師イメージクラスターと仕事の信念クラスター

\begin{tabular}{|c|c|c|c|c|c|c|c|c|c|c|}
\hline \multirow{2}{*}{$\begin{array}{c}\text { 教師イメージ } \\
\text { クラスター }\end{array}$} & \multicolumn{2}{|c|}{ 自己実現型 } & \multicolumn{2}{|c|}{ 生徒重視型 } & \multicolumn{2}{|c|}{ 開放的信念型 } & \multicolumn{2}{|c|}{ 独善型 } & \multicolumn{2}{|c|}{ 閉鎖的信念型 } \\
\hline & $\%$ & $\mathrm{n}$ & $\%$ & $\mathrm{n}$ & $\%$ & $\mathrm{n}$ & $\%$ & $\mathrm{n}$ & $\%$ & $\mathrm{n}$ \\
\hline 支援者型 & 20.6 & (67) & 22.8 & (74) & 32.0 & (104) & 15.4 & $(50)$ & 9.2 & (30) \\
\hline 管理者型 & 29.2 & (87) & 25.8 & $(77)$ & 10.7 & $(32)$ & 16.1 & $(48)$ & 18.1 & (54) \\
\hline 合計 & 24.7 & (154) & 24.2 & (151) & 21.8 & (136) & 15.7 & (98) & 13.5 & (84) \\
\hline
\end{tabular}

10年未満の教師には「管理者型」が多く, 経験 年数 10 年以上の教師には「支援者型」が多い傾 向にあったささらに，「理想像の変容」の有無に よる各クラスターの割合について分析した結果 (5-2)， $0.1 \%$ 水準で有意な差が認められ，理想と する授業像が変容した教師に「支援者型」が多く, 変容していない教師に「管理者型」が多かった.

2）「仕事の信念」クラスターの一般的傾向 次に,「経験年数グループ」ごとにみた「仕事 の信念」クラスターの比率について分析を行った 結果 $(5-3), 0.1 \%$ 水準で有意な差が認められ， 経験年数の少ない教師に「生徒重視型」が多く, 経験年数の多い教師に「自己実現型」の教師が多 い傾向にあった。さらに, 経験年数 10 年未満の
グループに比べ， 10 年以上のグループには「独 善型」の割合が比較的多い。一方，「閉鎖的信念 型」や「開放的信念型」については, 経験年数グ ループごとに大きな偏りが見られない。つまり， 開放的な信念を持つ体育教師と閉鎖的な信念をも つ体育教師は, 教職経験年数に関わらず存在する.

3）「仕事の信念」クラスターと「教師イメー シ」クラスターとの関係

「教師イメージ」クラスターごとの「仕事の信 念」クラスターの比率について分析を行った結果 (5-4)， $0.1 \%$ 水準で有意な差が認められた。特 に，教師イメージに関する「支援者型」の教師に は「開放的信念型」の教師が著しく多く，「管理 者型」の教師には，「閉鎖的信念型」の教師が多 
い傾向にある。

\section{2. 体育教師の経験と成長（分析 2)}

（1）「成長経験の受容」の構造

「成長経験の受容」に対する因子分析を行った
結果，5 因子が抽出された（表 6).

第 I 因子は，反省や内省を通じ，生徒とのコミ ュニケーションや新しいアイディアなどについて 試行錯誤しながら実践を行う経験と解釈されるた め, この因子を「省察的実践経験」と命名した.

表 6 成長経験の受容の因子分析結果

\begin{tabular}{|c|c|c|c|c|c|c|c|c|c|}
\hline & & I & II & III & N & $\mathrm{V}$ & 共通性 & $M$ & S.D. \\
\hline \multicolumn{10}{|l|}{ I～省察的実践経験 $(\alpha=.880)$} \\
\hline 授業の振り返りや反省をして次の授業にいかすこと & & .784 & -.161 & .000 & .151 & .014 & .654 & 4.20 & .81 \\
\hline 生徒とのコミュニケーションを積極的に困ること & & .744 & -.170 & .033 & -.047 & .084 & .495 & 4.26 & .80 \\
\hline 新しいアイデアを積極的に取り入れて授業をしてみること & & .740 & .022 & -.034 & .022 & -.031 & .538 & 3.94 & .86 \\
\hline “自分の授業はこれでいいのか”と常に授業のあり方を問い直すこ & & .719 & -.039 & -.054 & .055 & .015 & .508 & 4.16 & .86 \\
\hline 教材に関する知識を得ること & & .638 & .160 & -.029 & -.021 & -.040 & .476 & 3.79 & .88 \\
\hline 生徒の発育発達や心理的特徵等について知識を得ること & & .577 & .203 & -.044 & -.079 & .071 & .455 & 3.75 & .88 \\
\hline 教育にかかわらず幅広い教養を身につけること & & .575 & .046 & .053 & -.180 & .117 & .359 & 4.06 & .85 \\
\hline 同僚同士で授業に関わる議論をすること & & .487 & .055 & .011 & .255 & -.001 & .507 & 3.76 & .89 \\
\hline 授業において自分なりの達成感や充実感を感じること & & .432 & .081 & .209 & -.030 & .014 & .367 & 3.85 & .95 \\
\hline \multicolumn{10}{|l|}{ II 知識の獲得経験 $(\alpha=.891)$} \\
\hline 教育関係の専門雑誌や専門書を読むこと & & .045 & .867 & .050 & -.098 & -.045 & .718 & 2.90 & .96 \\
\hline 行政研修に参加して知識・情報を得ること & & -.190 & .847 & -.024 & .011 & .100 & .617 & 2.54 & .99 \\
\hline 体育科教育関係の専門雑誌や専門書を読むこと & & .162 & .766 & .069 & -.117 & -.088 & .644 & 2.99 & .98 \\
\hline 学校外で行われる任意の研究会に参加すること & & .038 & .732 & -.036 & .103 & -.090 & .596 & 2.75 & .97 \\
\hline 指導主事や専門的な研究者の意見を聞くこと & & -.054 & .666 & .000 & .191 & -.025 & .559 & 2.94 & 1.00 \\
\hline 指導要領や指導書を熟読すること & & -.056 & .639 & -.023 & .083 & .029 & .433 & 2.71 & 1.04 \\
\hline 地域社会の活動に参加すること & & .137 & .488 & -.029 & -.040 & .194 & .401 & 2.97 & 1.02 \\
\hline \multicolumn{10}{|l|}{ III 教員間対話経験 $(\alpha=.866)$} \\
\hline 学校外の保健体育教師から肯定的な意見をもらうこと & & .082 & .019 & .884 & -.011 & -.166 & .746 & 3.55 & .97 \\
\hline 学校内の同僚から肯定的な意見をもらうこと & & .116 & -.009 & .776 & .045 & -.187 & .625 & 3.61 & .96 \\
\hline 学校外の保健体育教師から批判的な意見をもらうこと & & -.149 & .029 & .720 & .005 & .264 & .655 & 3.43 & 1.08 \\
\hline 学校内の同僚から批判的な意見をもらうこと & & -.086 & -.032 & .689 & .039 & .245 & .629 & 3.51 & 1.01 \\
\hline \multicolumn{10}{|l|}{$\mathrm{N}$ 実践の参照·公開経験 $(\alpha=.822)$} \\
\hline 学校外の授業公開に参加して授業を見ること & & -.049 & .151 & -.024 & .796 & -.024 & .695 & 3.50 & .98 \\
\hline 同僚の授業を参観すること & & .021 & -.060 & .136 & .787 & -.018 & .719 & 3.73 & .93 \\
\hline 自分の授業を積極的に公開すること & & .108 & .104 & -.008 & .488 & .151 & .501 & 3.56 & 1.01 \\
\hline \multicolumn{10}{|l|}{$\mathrm{V}$ 困難経験 $(\alpha=.833)$} \\
\hline 予想と異なる反応をする生徒に出会うこと & & .095 & -.026 & .004 & .025 & .774 & .694 & 3.60 & 1.01 \\
\hline \multicolumn{2}{|l|}{ 解決が難しい問題場面を多く経験すること } & .152 & .022 & -.022 & -.012 & .697 & .606 & 3.70 & .95 \\
\hline 因子負荷平方 & & 7.376 & 6.593 & 5.607 & 6.143 & 4.178 & & & \\
\hline 因子間相関行列 & I & & & & & & & & \\
\hline & II & .540 & & & & & & & \\
\hline & III & .513 & .424 & & & & & & \\
\hline & N & .602 & .552 & .598 & & & & & \\
\hline & $\mathrm{V}$ & .519 & .313 & .451 & .452 & & & & \\
\hline
\end{tabular}

†主因子法プロマックスによる. 因子負荷 0.4 以上を太字で表記. 
第洇子は，あらゆる機会を通じて，教育実践に 関わる知識や情報を獲得する経験と解釈されるた め「知識の獲得経験」と命名した．第而因子は, 学校内外に打ける教員との対話経験と解釈される ことから「教員間対話経験」と命名した．第 $\mathbb{N}$ 因 子は，他教師の実践を見たり，自らの実践を見せ たりする経験と解釈されるため「実践の参照・公 開経験」と命名した．第 $\mathrm{V}$ 因子は，教師にとって 思い通りに実践が展開できないような困難な経験 と解釈されるため「困難経験」と命名した。

なお，各項目の記述統計量を見ると，「知識の 獲得経験」に高い負荷量を示した項目の平均値が 他の項目に比べて明らかに低く，いずれも中間值 （3 点）に達していない点に特徵が見られる.

(2)「経験年数グループ」による「成長経験の 受容」の比較

次に，経験の受け入れ方が経験年数によってど のように異なるかを検討するため,「成長経験の 受容」の因子得点を従属变数,「経験年数グルー プ」を独立変数とする一要因分散分析を行った （表 7，図 1)。分析の結果，「省察的実践経験」 「教員間対話経験」「実践の参照・公開経験」「困 難経験」について，0.1\%水準で有意な差が認め られ, 経験年数の多いグループほど值が低い傾向 にあった。

\section{(3)「成長経験の受容」と「理想像の変容」と の関連}

「成長経験の受容」と「理想像の変容」との関 連を検討するため，経験年数グループごとに，理 想像の变容の有無による因子得点平均の比較 $(\mathrm{t}$ 検定）を行った（表 8)。分析の結果 “10年未満”
では「省察的実践経験」のみ，“10年以上 20 年未 満”では「知識の獲得経験」と「実践の参照・公 開経験」，そして“20年以上”では全ての因子で 有意な差が認められ，いずれも変容群の平均值が 高かった。このことから，理想像の変容と成長経 験の受容が関連しており，経験年数を積んだ教師 においてその関連がより密接といえる。

\section{3. 体育教師が保有する信念の機能（分析 3）}

（1）「仕事の信念」と「成長経験の受容」の関 連

次に，仕事の信念と成長経験の受容との関係を 検証するため,「仕事の信念」クラスターごとに 「成長経験の受容」の因子得点平均を比較した (図 2). 分析の結果， $0.1 \%$ 水準でクラスター間 に有意な差が認められ，「開放的信念型」「生徒重 視型」「独善型」「自己実現型」「閉鎖的信念型」 の順に值が低くなる傾向にある，特に，全ての因 子得点に抢いて「開放的信念型」と「閉鎖的信念 型」の間に大きな差異が認められた.

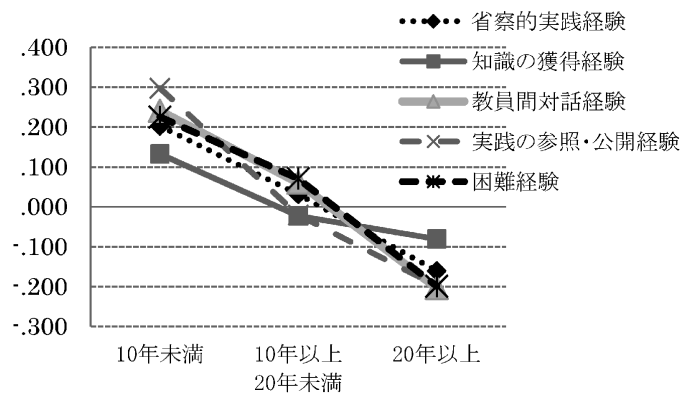

図1 経験年数グループ別にみた成長経験の受容

表 7 経験年数グループによる成長経験の受容の比較分析結果

\begin{tabular}{ccccc}
\hline & 10年未満 & 10年以上20年未満 & 20年以上 & $F$ 值 \\
\hline 省察的実践経験 & $.203(.860)$ & $.031(.958)$ & $-.161(.980)$ & $8.59^{* * *}$ \\
知識の獲得経験 & $.133(.986)$ & $-.023(.988)$ & $-.080(.909)$ & $2.89^{\text {n.s. }}$ \\
教員間対話経験 & $.241(.941)$ & $.060(.898)$ & $-.204(.935)$ & $13.45^{* * *}$ \\
実践の参照·公開経験 & $.297(.863)$ & $-.020(.932)$ & $-.198(.921)$ & $16.95^{* * *}$ \\
困難経験 & $.225(.834)$ & $.071(.891)$ & $-.199(.919)$ & $13.62^{* * *}$ \\
\hline
\end{tabular}

†（ ）内は標準偏差 
表 8 理想像の変容有無による成長経験の受容の比較分析結果

\begin{tabular}{|c|c|c|c|c|c|c|c|c|c|}
\hline & \multicolumn{3}{|c|}{ 10年未満 } & \multicolumn{3}{|c|}{10 年以上 20 年未満 } & \multicolumn{3}{|c|}{ 20年以上 } \\
\hline & $\begin{array}{l}\text { 変容群 } \\
(\mathrm{n}=82)\end{array}$ & $\begin{array}{c}\text { 非変容群 } \\
(\mathrm{n}=111)\end{array}$ & $t$ 值 & $\begin{array}{l}\text { 変容群 } \\
(\mathrm{n}=64)\end{array}$ & $\begin{array}{c}\text { 非変容群 } \\
(\mathrm{n}=92)\end{array}$ & $t$ 値 & $\begin{array}{c}\text { 変容群 } \\
(\mathrm{n}=132)\end{array}$ & $\begin{array}{l}\text { 非変容群 } \\
(\mathrm{n}=142)\end{array}$ & $t$ 值 \\
\hline 省察的実践経験 & $\begin{array}{l}.387 \\
(.765)\end{array}$ & $\begin{array}{l}.066 \\
(.903)\end{array}$ & $2.603^{* *}$ & $(1.026)$ & $\begin{array}{l}-.075 \\
(.898)\end{array}$ & 1.668 & $\begin{array}{l}.054 \\
(.916)\end{array}$ & $\begin{array}{c}-.360 \\
(.998)\end{array}$ & $3.563^{* * *}$ \\
\hline 知識の獲得経験 & $\left(\begin{array}{c}.195 \\
(1.001)\end{array}\right.$ & $\begin{array}{l}.086 \\
(.976)\end{array}$ & .759 & $\begin{array}{c}.251 \\
(1.050)\end{array}$ & $\begin{array}{l}-.213 \\
(.900)\end{array}$ & $2.960^{* *}$ & $\begin{array}{l}.067 \\
(.883)\end{array}$ & $\begin{array}{c}-.217 \\
(.914)\end{array}$ & $2.611^{* *}$ \\
\hline 教員間対話経験 & $\begin{array}{l}.338 \\
(.910)\end{array}$ & $\begin{array}{l}.169 \\
(.961)\end{array}$ & 1.234 & $\begin{array}{l}.163 \\
(.882)\end{array}$ & $\begin{array}{l}-.011 \\
(.907)\end{array}$ & 1.190 & $\begin{array}{l}-.068 \\
(.797)\end{array}$ & $\begin{array}{c}-.330 \\
(1.034)\end{array}$ & $2.355^{*}$ \\
\hline 実践の参照·公開経験 & $\begin{array}{l}.401 \\
(.821)\end{array}$ & $\begin{array}{l}.221 \\
(.889)\end{array}$ & 1.436 & $\begin{array}{l}.163 \\
(.931)\end{array}$ & $\begin{array}{l}-.148 \\
(.916)\end{array}$ & $2.068^{*}$ & $\begin{array}{l}-.059 \\
(.828)\end{array}$ & $\begin{array}{c}-.327 \\
(.985)\end{array}$ & $2.446^{*}$ \\
\hline 困難経験 & $\begin{array}{l}.275 \\
(.811)\end{array}$ & $\begin{array}{l}.188 \\
(.853)\end{array}$ & .711 & $\begin{array}{l}.082 \\
(.964)\end{array}$ & $\begin{array}{l}.063 \\
(.841)\end{array}$ & .131 & $\begin{array}{l}-.085 \\
(.887)\end{array}$ & $\begin{array}{c}-.304 \\
(.938)\end{array}$ & $1.982^{*}$ \\
\hline
\end{tabular}

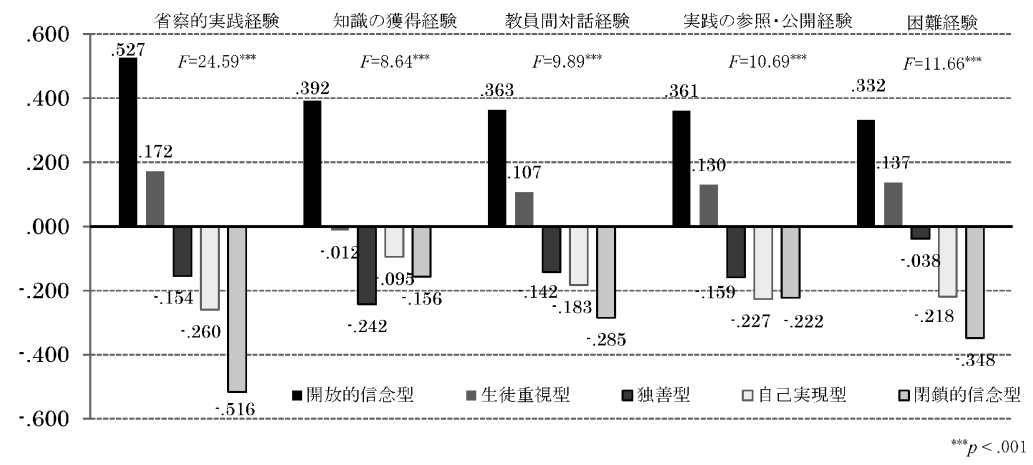

図 2 仕事の信念クラスターによる成長経験の受容の分散分析結果

（2）「成長経験の受容」に対する「仕事の信念」

\section{および「教職経験年数」の影響}

これまでの分析において，教職経験年数を積ん だ教師ほど「成長経験の受容」が低い傾向にあっ た. 一方，「仕事の信念」クラスターによって， 「成長経験の受容」が異なることも明らかになっ た．以上を踏まえて，教師の成長に打ける信念の 機能をより詳細に検討するため, 重回帰分析によ って「成長経験の受容」に対する「仕事の信念」 と「教職経験年数」の相対的な影響力を分析した. 分析の結果, 全ての重回帰式に扔いて有意な決 定係数が得られた（表 9). 各变数の相対的な影 響力を示す標準化偏回帰係数 $(\beta)$ をみると, $\lceil$ 公共的価值の重視」「先導的実践の追求」「生徒 重視」が全ての成長経験の受容に対して有意な正
の影響力を有していた. なお，決定係数の值が比 較的高かった「省察的実践経験」と「知識の獲得 経験」については, 教職経験年数の影響が有意で はなく，仕事の信念によって「成長経験の受容」 が規定されていた。ただし，「専門的閉鎖性」お よび「自律性の行使」は負の影響力を示している.

他方,「教員間対話経験」「実践の参照・公開経 験」「困難経験」に対しては, 教職経験年数の負 の影響が示され，また，後二者については，「専 門的閉鎖性」の有意な負の影響も示された。 
表 9 成長経験の受容に対する仕事の信念と教職経験年数の重回帰分析結果

\begin{tabular}{|c|c|c|c|c|c|}
\hline & $\begin{array}{c}\text { 省察的実践経験 } \\
\beta\end{array}$ & $\begin{array}{c}\text { 知識の獲得経験 } \\
\beta\end{array}$ & $\begin{array}{c}\text { 教員間対話経験 } \\
\beta\end{array}$ & $\begin{array}{c}\text { 実践の参照·公開経験 } \\
\beta\end{array}$ & $\begin{array}{c}\text { 困難経験 } \\
\beta\end{array}$ \\
\hline $\begin{array}{l}\text { 公共的価值の重視 } \\
\text { 職務に抢䂓己実現 }\end{array}$ & $.186^{* * *}$ & $.225^{* * *}$ & $.173^{* * *}$ & $.176^{* * *}$ & $.132^{* * *}$ \\
\hline 先導的実践の追求 & $.288^{* * *}$ & $.141^{* * * *}$ & $.109^{* *}$ & $.158^{* * *}$ & $.156^{* * *}$ \\
\hline 生徒重視 & $.223^{* * *}$ & $.127^{* * *}$ & $.160^{* * *}$ & $.164^{* * *}$ & $.145^{* * *}$ \\
\hline 自律性の行使 & & $-.078^{*}$ & & & \\
\hline 専門的閉鎖性 & $-.192^{* * *}$ & & & $-.129^{* * *}$ & $-.135^{* * *}$ \\
\hline 研究志向 & $.095^{* *}$ & $.275^{* * *}$ & $.076^{*}$ & & \\
\hline 教職経験年数 & & & $-.182^{* * *}$ & $-.140^{* * *}$ & $-.153^{* * *}$ \\
\hline$R^{2}$ & $.300^{* * *}$ & $.212^{* * *}$ & $.154^{* * *}$ & $.188^{* * *}$ & $.153^{* * *}$ \\
\hline
\end{tabular}

\section{$\mathrm{N}$ ．考察}

\section{1. 信念の構造と体育教師の類型にみられる特 徵}

体育教師の信念については「教師イメージ」が 4 つ，「仕事の信念」が 7 つの因子によって構成 されていた．特に，「仕事の信念」において抽出 された因子は，Hall（1968）の枠組みや田尾 （1983）の結果と対応するものが多く，一般的な 専門職のそれと近似していた。専門職の要件には 複数の所論が存在するが，「長期教育により獲得 する理論・知識」と利他主義, 公共の奉仕を志向 した行動規範としての「倫理的規範」が共通要件 とされる（宮下，2001，pp. 14-15）。特に，本研 究で抽出された「公共的価值の重視」「生徒重視」 「先導的実践の追求」は，これらの要件に相当程 度対応しており，体育教師の仕事の信念が一般的 な専門職の信念と同様の構造を有しているといえ よう.

その後「教師イメージ」の信念に基づいて体育 教師を類型化した結果，「支援者型」と「管理者 型」のクラスターが抽出され，ベテランの教師及 び理想像が变容した教師に「支援者型」が多い傾 向がみられた。秋田（1996）の研究では，学生 や新任教師が授業を「伝達の場」と捉えるのに対 し, 中堅教師は「共同作成の場」として捉える傾 向にあることが報告されている，さらに「伝達の
場」は「権力者」の教師イメージと,「共同作成 の場」は「導く者」の教師イメージと, 関連して いた。このことは，熟達に伴って，授業を教師と 子どもの相互作用からなる複雑な過程とみなす傾 向を表して抢り，イメージの変容にみられる方向 性を示している.

若手よりもべテランの教師に「支援者型」が多 いという本研究の結果も, 教師の一方的な指導を 強調するのではなく，その役割を生徒と学習成果 を結びつける双方向的で複雑な関係の中に見出し ている点で, 熟達に伴うイメージの変化と重な る.さらに,「理想像の変容」が生じた教師に 「支援者型」が多かった点を踏まえると，体育教 師の授業に関する理想像の变容に教師としての熟 達が含意されていると考えられる.

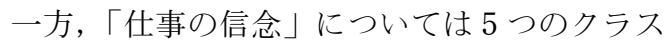
ターが抽出され，経験年数を重ねた教師ほぞ「生 徒重視型」よりも「自己実現型」や「独善型」の 教師が多い傾向を確認した. 経験年数の浅い教師 の多くは, 日々の授業や目の前に存在する生徒へ の対応が大きな課題となり，また他教師との関係 性の中で教職へと適応していくことが求められ る.これに対して，経験を積み授業内外における 自律的な意思決定が可能となっていくに従って, 自らの潜在的な可能性の実現を志向したり，職務 の中でより自律的な意思決定を重視したりする体 育教師が増えていくと解釈できよう.

また，「教師イメージ」クラスターと「仕事の 
信念」クラスターとのクロス集計では「支援者型」 に「開放的信念型」が多く，「管理者型」に「閉 鎖的信念型」が多い傾向にあった。授業を複雑な 過程とみなす支援者型の教師にとっては，その複 雑さに対応するための新たな実践や試行錯誤が不 可避的に生じると考えられる. そのことが開放的 な仕事の信念を喚起するか, あるいは逆に, 開放 的な信念を構成している先導的実践の追求や研究 志向の高さが，高次のイメージを喚起するとも考 えられよう. その因果関係の同定は困難である が，授業像の変容が「支援者型」と関係していた ことを踏をえると, 開放的な仕事の信念が教師の 成長にとって重要な役割を果たしていることが指 摘できる.

\section{2. 体育教師の成長に関する一般的傾向}

体育教師の「成長経験の受容」を構成する 5 つの因子得点平均については, 経験年数グループ ごとに有意な差が認められ，いずれの因子におい ても, 経験年数の多いグループほど值が低かっ た、体育教師を含む教師のキャリア研究において も, 経験年数の蓄積に伴う停滞現象が報告されて いる（西, 1990 ; 高井良, 1994 ; 小山ほか, 1994; Stroot and Ko, 2007). 本研究の分析結果は 横断的なデータに基づくため, 経験年数の蓄積に 伴って経験の受け入れに対する積極性が低下す る，と経時的な観点から解釈するには必ずしも十 分ではない，そのことを踏まえた上で考察する と, 本研究の分析結果は経験豊かな教師が, 自ら の信念を有意味に構造化していく反面, 斬新な経 験に動摇しなくなり，マンネリを生み出す「成長 の落とし穴」（梶田，1986, pp. 172-174）の現象 を示唆している. つまり, 経験年数を蓄積するこ とによって, 経験の受け入れが硬直化したり固定 化したりする現象が，体育教師にも起こることを 窺わせるものである.

「理想像の変容」の有無による比較では, 変容 群において「成長経験の受容」の值が高かった.

このことは, 経験や出来事に対する積極的な意味 付けを行うこと（岸野・無藤，2006）が，信念 やイメージの変容としての成長（秋田，1996；
Guskey，2002）を促すことを示す。また，経験 年数別に見ていくと, ベテランの教師ほど多様な 成長経験をいかに受け入れるかが理想像の変容と 大きく関わっていた。

“10年未満”の教師は, 授業を成立させること や試行錯誤しながら指導経験を積むこと自体が課 題となる. 故に, 成長に関わる経験の中で最も基 本的といえる「省察的実践経験」が授業像の変容 と関連していると考えられる。“10年以上 20 年未 満”の中堅教師になると, 実践を支えている知識 の獲得や他者の実践を参照するなど, 新たな知識 や情報, 教授技術に触れる経験が授業像の形成や 刷新と関わることになる．そして，“20年以上” のベテラン教師では, 授業の理想像が変わるか変 わらないかが，多様な経験を如何に解釈し意味づ けるかによって大きく異なることが示唆される. つをり, 量的には経験を積んでいるべテラン教師 こそ, 個々の経験を積極的に受け入れることが成 長にとって重要な意味をもつと推察される.

\section{3. 成長経験の受容に対する信念の機能}

「仕事の信念」のクラスター別に「成長経験の 受容」を比較した結果, 如何なる仕事の信念を持 つ教師であるかによって, 成長経験の受け入れ方 が異なっていた，とりわけ，開放的な信念を保有 する教師と閉鎖的な信念を保有する教師の間に は, 経験の受け入れ方に大きな違いがあった。こ れは「「開いた心と閉ざされた心」(Rokeach， 1960）といった信念体系の構造的な違いから説 明できる，開いた心は，自らの信念を否定するよ うな「非信念」（disbelief）に対する寛容性が相 対的に高いが，閉ざされた心は自分の信頼する権 威のみに従い, 非信念を排斥する（善明, 1992). 成長経験を未知の情報や新たな情報が含 意している「非信念」に接触する機会と捉えると, 開放的な信念と閉鎖的な信念の違いが，経験に対 する寛容性や感受性の違いとなって現れると解釈 できる.

さらに重回帰分析の結果, 成長経験の受容は信 念によって促進されるだけでなく, 阻害されるこ とが示された．「仕事の信念」の機能を俯瞰する 
々「公共的価值の重視」「先導的実践の追求」「生 徒重視」「研究志向」の信念が成長経験の受容を 促し,「教職経験年数」と「専門的閉鎖性」,「自 律性の行使」がそれを阻害するといった関係性が 看取できる，つまり，成長経験の受け入れを促進 する開放的な信念と，それらを阻害する閉鎖的な 信念及び教職経験年数が，互いに相反する機能を 有していることがわかる。

特に，全ての成長経験の受容を促していたの は，体育教師の仕事が公共的な価值を有する重要 な位置を占め, 自らの職業が社会を先導すること を意識し, 常に教育活動の対象である生徒のこと を思う，といった職務の社会的な価值に対する 「誇り」ともいうべき信念である。特に，仕事に 対する「誇り」は，複雑かつ不確実性の高い困難 な課題に取り組まなければならない時などに仕事 への動機づけを支える要因となる（藤田，2000； 平田，2002).さらに，信念の構造において考察 したように，これらは専門職の共通要件にあたる 信念であることから，専門職としての誇りとも言 い換えることができよう.

一方，負の影響を示した信念である「専門的閉 鎖性」は，「省察的実践経験」をはじめ実践に直 接関わる成長経験の受容を妨げており，「強固な 信念」（竹下，1996）として機能しやすい性質を 持っている. 故に，体育教師としての職務に伴う 専門的な閉鎖性を乗り越えなければ，教職の本質 である省察的経験の受け入れが制限されることに なろう。また，「自律性の行使」についても同様 のことが指摘できる.

以上を総括すると，経験年数の蓄積と閉鎖的な 信念が，経験に対する感受性を低下させ固定化や 硬直化を引き起こす「成長の落とし穴」や「停滞」 を助長するのに対し，開放的な信念，特に，体育 教師の専門職としての誇りともいうべき信念が， 経験の積極的な受け入れと体育教師としての成長 を支えている，と考えられる．

\section{V. 結 語}

本研究は，体育教師自身のものの見方・考元方
の変容という観点からみた成長を規定する要因を 解明するため, 成長に不可欠な経験の受け入れを 規定する信念一一教師イメージ」と「仕事の信 念」の構造と機能を明らかにすることを目的とし た．主要な結果は，以下の通りである.

(1) 体育教師の「教師イメージ」は，「誘導者」 「管理者」「学習支援者」「協力者」の 4 因子 からなる構造を有していた。また，体育教師 の「仕事の信念」は，「公共的価值の重視」 「職務に抢ける自己実現」先導的実践の追求」 「生徒重視」「自律性の行使」「専門的閉鎖性」 「研究志向」の 7 因子からなる構造を有して いた。

（2）保有している信念の特徵から,「教師イメー ジ」については「管理者型」と「支援者型」 という 2 つタイプ,「仕事の信念」につい ては「自己実現型」「生徒重視型」「開放的信 念型」「独善型」「閉鎖的信念型」という 5 つのタイプに類型化された. また, 若手の体 育教師には「管理者型」と「生徒重視型」が, ベテランの体育教師には「支援者型」「自己 実現型」「独善型」が多い傾向にあった。さ らに，体育教師の成長にとっては「支援者型」 と「開放的信念型」の信念が重要であった.

（3）「成長経験の受容」は，「省察的実践経験」 「知識の獲得経験」「教員間対話経験」「実践 の参照 ·公開経験」「困難経験」の 5 因子で 構成されており，「知識の獲得経験」を除く 4 つの経験については, 経験年数を積んだ体 育教師ほど，経験の受容に対して消極的な傾 向が認められた。 また，ベテランの体育教師 ほど，授業の理想像の変容が多様な成長経験 の受容と密接に関連していた。

（4）成長経験の受け入れは，体育教師の「仕事 の信念」のタイプによって異なっていた．特 に「開放的信念型」と「閉鎖的信念型」の間 に大きな差異が認められ, 前者は全ての成長 経験を積極的に受容するが，後者は全ての経 験に対して消極的であった，また，体育教師 の成長経験の受け入れは, 教職経験年数と仕 事の信念によって規定されていた。ただし， 
「公共的価値の重視」「先導的実践の追求」

「研究志向」の信念が経験の受容を促すのに 対し，「自律性の行使」「専門的閉鎖性」「教 職経験年数」が経験の受容を阻害することが 明らかとなった。

最後に, 今後の研究課題と体育教師の成長に関 する実践的課題について言及したい，本研究の結 果から，体育教師の成長に深く関係する経験から の学習が, 教師の役割をより複雑なものとして捉 える信念や，専門職としての誇りともいうべき信 念に支えられていることが明らかとなった．同時 に，公共への奉仕に対する信念や専門職としての 誇りを持ち，自らのものの見方・考え方を刷新し ていく体育教師が存在する一方, 閉鎖的な信念を 保有し, 成長が停滞している教師が確かに存在す ることが示唆された．ただし本研究で用いた定量 的方法は, 分類と比較を通じて, 信念の構造と機 能や保有する信念に基づく一般的な教師類型を提 示するのに有効であるが，信念の形成・変容にみ られるダイナミズムを捉えるには不十分である. また, 現実の体育教師は, 常に学校や同僚, 生徒 によって構成される社会的文脈の中で実践を展開 しているため，信念と実際の行動を単純に結び付 けることはできない。故に，体育教師は学校現場 に掞いて，他者からどのような影響を受け，信念 をどのように表出するのか, さらに, 特定の信念 が形成・強化されやすい環境について検討してい く必要がある. 本研究は一貫して, 教師自身の自 己評価に基づき, 分析的に体育教師の信念に接近 したが，体育教師の信念を実際の生活や行為に沿 って記述・説明していく事例的研究の展開が求め られる。

成長に関する実践的課題については，経験を一 方的に提供するような養成・研修体制を見直す必 要がある. 本研究の結果からは, いかに良質な経 験を体系化したプログラムも，その成否が体育教 師の専門職としての信念に左右されることが示唆 された。ある経験には，常に外的経験（経験の対 象となる客観的状況）と内的経験（学習者の内的 状態）が含をれる（松尾，2006, pp. 58-59）。体 育教師の成長を支えるためには, 外的な経験内容
を重視した養成・研修機会のみならず，内的経験 にも目を向け，教師が自らの信念を問い直し，時 にはその変容を促すようなジレンマが生じる柔軟 な機会の創造が求められる，つまり，体育教師が 自らの信念について深く省察する学びの場をいか に構築していくかが課題となろう.

\section{付記}

本研究は文部科学省科学研究費補助金（基盤研 究 (C) 課題番号: 20500533, 研究代表者: 清水 紀宏）の助成を受けて実施されたものである.

注

注 1）木原（2011）のレビューによれば，欧米に拈い ては主に質的研究法によって体育教師の成長過程 を明らかにする試みがなされているものの, 我が 国の体育教師を対象として成長過程を明らかにし ようとした研究はほとんどない。

注 2) 信念と知識との峻別は明確になされていないが (Kagan, 1992; Pajares, 1992; Richardson, 1996 ; 秋田，2000)，その違いとして知識が事実である のに対して，信念は意見であること（Kagan， 1992）や信念が評価や判断に基づくのに対して, 知識は客観的な事実に基づくこと（Pajares, 1992), また, 教師の知識研究で扱いきれない暗 黙的な知を信念研究が扱っているという見解（姫 野，2002）などが提起されている.

注 3) Jewett and Bain (1985, pp. 21-39) によれば, 主な価值志向性（value orientation）として「学 問的修得 (disciplinary mastery)」を最も伝統的 な価值志向性として, その他「社会的再構成 (social reconstruction) 」「自己実現（self-actualization)」「学習過程 (learning process)」「生態学 的妥当性（ecological validity）」の 5 つに分類さ れている。

注 4）被教育体験期の影響とは, 教師の教育行為が, 自らが児童生徒であった時の体験に規定されるこ とを指しており，Lortie（1975）の提唱した「観 察の徒弟制 (apprenticeship of observation)」(p. 65)による教師の職業的社会化とも共通している.

注 5）本研究は, 個性記述的な事例研究の方法的意義 や研究蓄積を否定するものではない. 信念の構造 や教師の信念タイプに関わる一般的傾向を明らか にすることで, 蓄積されてきた事例の特徵やこれ から蓄積されていく事例のもつ意味や意義を明確 
にすることに資すると考える．

注 6) 本研究の枠組みは, 教育心理学, (体育) 教師 教育研究, 経営学に打快人材育成研究にまたが る学際的なものである.だが，これらの学問領域 では, 知識の伝達者から教えることについて熟 慮· 内省し長期的に学んでいく教師像の提起, 人 的資源としてのヒトを管理の対象ではなく成長す る主体と捉える人材観への転換等の学術的な動向 が見られ，学習を通じたヒトの成長を問題とする 点に沶いて近接しつつある.さらに，その学習を 如何に支援するかあるいはヒト（教師）は如何に 学ぶか, といった実践的課題を有している点で相 互に重なり合うものといえよう.

注 7）心配事については, Fuller（1969）の研究にお ける枠組みが挙げられている。

注 8）信念の内部構造を踏まえると，ここで挙げた 5 つないしは10のカテゴリーに対応する信念もまた 相互に関連しつつ， ある信念が他の信念に影響を

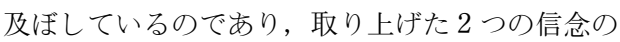
重要度が相対的に高いかどうかについては推論の 域を脱しえない. 本研究では, 先行研究の知見と 研究の枠組みおよび操作化の可能性などを考慮 し,「教師イメージ」と「仕事の信念」に限定し て構造と機能を検討しているが，Calderhead （1996）と Tsangaridou（2006）がカテゴリー化 した他の信念の構造，さらにはカテゴリー化され た信念間の関係を検証していくことは，体育教師 の信念の全体像を明らかにする上で重要な研究課 題であることを付言しておきたい

注 9） Elbaz（1981）は，実践的知識の構造について 「実践のルール」「実践の原理」「イメージ」の 3 つのレベルを提示し，イメージは最も包括的で非 明示的であるとする．また，イメージは教師の思 考を導き, 関連する領域の知識を構造化するのに 役立ち，直観的な認識を導くとともに価值判断を 含むものとされている.

注10） Hall（1968）は専門職（プロフェッション）の 態度特性として(1)外部の職能団体への準拠，(2)同 僚の統制, (3)公共へのサービスの信念, (4)天職と しての内面化，(5)自律性の行使をあげ，50項目で 尺度を構成した. Snizek（1972）はこの尺度を改 良し，30の項目で専門職への態度構造を測定する 尺度を開発した。また，田尾（1983）は以上の先 行研究をもとに，30項目の質問を構成し「専門性」 「自己実現」「自律性 I」（責任の所在に関わる自 律性）「自律性 II」（実行過程に抢ける自律性） 「研究性」「クライエント重視」「集団的閉鎖性」
「同僚準拠」の 8 因子を抽出している.

注11）田尾（1980）も付言しているように，この尺度 は様々な分野において適用することを目的に開発 されたもので, 各分野の研究者の意向や工夫が反 映されていることから，部分的に特定の職業にお いて適切ではない項目が含まれている.

注12）「経験年数グループ」は，「10年未満」,「10年以 上 20 年未満」,「 20 年以上」の 3 群に分けた. 教師 研究の領域では, Berliner (1988) や吉崎 (1998), 木原（2004）などが教師のキャリアを 3 から 5 段 階に分けているが, 本研究では調査時に「保健体 育教師として大きく成長したと思う時期」を尋ね たところ，10年目，20年目が大きなピークとなっ ていたことから，上記の 3 群に分類している.

注13）授業像の変容に関する質問は「入職時」と比べ た時の理想像の変容の度合いを尋ねている.ここ で, 経験年数グループ別に分析を行うのは, 経験 年数の少ない教師と多い教師では, 理想像の変容 に対する捉え方が異なると考えられるからである.

注14） 尺度の信頼性を表す Cronbach の $\alpha$ 係数を算出 したところ，第吕因子，第 V因子，第林因子にお いて比較的低い值が示された. $\alpha$ 係数については 明確な基準があるわけではないが，概ね $0.7-0.8$ 以上が目安とされることが多いため,「仕事の信 念」について抽出された因子の内的整合性は十分 に高いとは言い難い。だが，尺度の再検討が求め られる0.5を切るような值ではなく（小塩，2004， p. 143), 項目数の少なさと抽出された因子の理論 的意義を勘案し，その後の分析に用いることとし た.

\section{文献}

Abelson, R.P. (1979) Differences between belief system and knowledge system. Cognitive science, 3 : 355-366.

Abelson, R.P. (1986) Beliefs are like a possession. Journal for the theory and social behavior, 16(3): 223-250.

秋田喜代美（1996）教える経験に伴う授業イメージの 変容一比喻生成課題による検討一. 教育心理学研究, 44: 76-186.

秋田喜代美 (2000) 教師の信念. 日本教育工学会編, 教育工学事典. 実教出版 : 東京.

秋田喜代美 (2009) 教師教育から教師の学習過程研究 への転回 : ミクロ教育実践研究への変貌. 矢野智司 ほか編, 変貌する教育学. 世織書房 : 東京, pp. 45- 
75.

安藤知子 (2000)「教師の成長」概念の再検討. 学校経 営研究, 22: 99-121.

Armour, K. (2006) Physical education teachers as career-long learners: A compelling research agenda. Physical education and sports pedagogy, 11: 203-207. 浅田 匡 (1998) 教師の自己理解. 浅田匡ほか編, 成 長する教師 : 教師学への誘い. 金子書房 : 東京, pp. 244-255.

朝倉雅史・清水紀宏（2010）体育教師の信念に関する エスノグラフィー研究. 体育 ・ スポーツ経営学研究,

24: $25-46$.

朝倉雅史 ·清水紀宏 (2011) 体育科教員への入職過程 と運動部活動を通じた経験：体育科教員のライフヒ ストリーに着目して、いばらき健康・スポーツ科学, 28: $1-17$.

朝倉雅史・清水紀宏（2012）体育授業に対する教師の 認識変容過程：小学校教師の長期研修を事例とし て. 筑波大学体育科学系紀要, 35: 165-181.

Bechtel, P.A. and O'sullivan, M. (2006) Effective professional development: What we now know. Journal of teaching in physical education, 25: 363-378.

Bechtel, P.A. and O'sullivan, M. (2007) Enhancers and inhibitors of teacher change among secondary physical educators. Journal of teaching in physical education, 26: 221-235.

Berliner, D. (1988) The development of expertise in pedagogy. AAC TE: Washington, D.C.

Bullough, R.V. and Baughman, K. (1997) "First-Year Teacher" Eight years later: An inquiry into teacher development. Teacher college press: New York.

Calderhead, J. (1996) Teachers: Beliefs and knowledge. Berliner, D.C. and Calfee, R.C. (Eds.) Handbook of educational psychology. Macmillan Library Reference: New York, pp. 709-725.

Deglau, D. and O'sullivan, M. (2006) The effects of a long-term professional development program on the beliefs and practices of experienced teachers. Journal of teaching in physical education, 25: 379-396.

デューイ：松野安男訳（1975）民主主義と教育（上）, 岩波書店 : 東京.

Elbaz, F. (1981) The teacher's "practical knowledge": Report of a case study. Curriculum inquiry, 11(1): 43 -71 .

Ennis, C.D. (1992a) Curriculum theory as practiced: Case studies of operationalized value orientations. Journal of teaching in physical education, 11: 358-
375.

Ennis, C.D. (1992b) The influence of value orientations in curriculum decision making. QUEST, 44: 317-329.

Ennis, C.D. (1994) Knowledge and beliefs underlying curricular expertise. QUEST, 46: 164-175.

Ennis, C.D., Cothran, D.J., and Loftus, S.J. (1997) The influence of teacher's educational beliefs on the knowledge organization. Journal of research and development in education, 30(2): 73-86.

Ennis, C.D. and Hooper, L.M. (1988) Development of an instrument for assessing educational value orientations. Journal of curriculum studies, 20 (3): 277-280.

Fishbein, M. and Ajzen, I. (1975) Belief, attitude, intention and behavior: an introduction to theory and research. Addison-Wesley: Boston.

藤木和巳 (2000) 実践的な教師教育研究の動向と教師 の信念体系. 教育実践学研究, 2(1): 59-68.

藤田英樹 (2000) 誇り動機づけ理論. 組織科学, 33 (4) : 59-75.

深見俊崇 (2006) 教師 ·教員志望学生の実践イメージ に関する研究動向と課題. 大阪市立大学大学院文学 研究科紀要人文研究, 57: 78-95.

深見俊崇 (2007) ある初任教師の実践イメージの変容 : 1 年間の事例研究を基に. 日本教育工学会論文誌, 30(4): 283-201.

深沢 宏. 対馬清造 (1982) 体育教師の職業的社会化 に関する実証的研究. 秋田大学教育学部教育研究所 報, 19: 32-41.

Fuller, F. (1969) Concerns of teachers: A developmental conceptualization. American educational research journal, 6: 207-226.

グッドソン：藤井 泰 ・ 山田浩之訳 (2001) 教師のラ イフヒストリー：「実践」から「生活」の研究へ. 晃 洋書房 : 京都.

グッドソン・サイクス：高井良健一・山田浩之訳 (2006) ライフヒストリーの教育学: 実践から方法論 まで. 昭和堂 : 京都.

Graber, K. (1995) The influence of teacher education programs on the beliefs of student teachers: General pedagogical knowledge, pedagogical content knowledge, and theacher education course work. Journal of teaching in physical education, 14: 157178.

Green, T. (1971) The activities of teaching. McGrawHill : New York, pp. 41-63.

Guskey, T.R. (2002) Professional development and teacher change. Teacher and Teaching: Theory and 
Practice, 8(3): 381-391.

Ha, A.S. and Xu, B. (2002) Comparison of physical education teacher's value orientation in Hong Kong and Shanghai. International sports studies, 24(1): 77-87.

Hall, R.H. (1968) Professionalization and bureaucratization. American sociological review, 33 (1): 92-104. 姫野完治（2002）協同学習を基盤とした教師教育の課 題と展望 : 教師の成長に関する研究動向から. 大阪 大学教育学年報, $7: 47-60$.

平田謙次 (2002) 誇り感情を媒介としたワークモチベー ション因果モデル. ソーシャルモチベーション研究, 1: $31-41$.

稲垣忠彦 · 寺崎昌男 ·松平信久 (1988) 教師のライフ コース. 東京大学出版会 : 東京.

Jewett, A.E. and Bain, L.L. (1985) The curriculum process in physical education. Wm. C. Brown: Dubuque.

Kagan, D.M. (1992) Implications of research on teacher belief. Educational psychologist, 27 (1): 65-90.

梶田正巳 (1986) 授業を支える学習指導論 PLATT. 金子書房 : 東京, pp. 181-195.

河村茂雄（2000）教師特有のビリーフが児童に与える 影響. 風間書房 : 東京.

木原成一郎 (2011) 専門職としての教師の成長過程と 支援体制。日本体育科教育学会編，体育科教育学の 現在. 創文企画：東京, pp. 193-207.

木原俊行 (2004) 授業研究と教師の成長. 日本文教出 版 : 大阪.

岸野麻衣・無藤隆（2006）教師としての専門性の向上 における転機：生活科の導入に関わった教師による 体験の意味づけ. 発達心理学研究, 17(3): 207-218.

Kolb, D.A. (1984) Experiential learning: Experience as the source of learning and development. PrenticeHall: New Jersey.

厚東芳樹 ·長田則子・梅野圭史（2010）アメリカの

Teaching Expertise 研究にみる教師の実践的力量に 関する文献的検討. 教育実践学論集，11: 1-13.

小山悦司·河野昌晴 · 村島義彦 ·曽我雅比児 · 妹尾純 子（1990）教師の自己教育力に関する調査研究：成 長の契機についての自己形成史的分析．岡山理科大 学紀要 B 人文·社会科学, 25: 117-137.

小山悦司 · 河野昌晴 - 赤木恒雄 - 加藤研治 - 別惣淳二 （1994）教師の自己教育力に関する調査研究 : 自己教 育力の構造的把握と経年的推移. 岡山理科大学紀要 B 人文・社会科学，30: 151-162.

Kulinna, P.H., Silverman, S., and Keating, X.D. (2000) Relationship between teacher's belief systems and ac- tion toward teaching physical activity and fitness. Journal of teaching in physical education, 19: 206221.

黒羽正見（1999）教育行為に表出する教師の信念に関 する事例的考察：公立 $\mathrm{S}$ 小学校対象のエスノグラフ ィーを通して. 日本教師教育学会年報, 8: 89-97.

楠見 孝 (1999) 中間管理職のスキル, 知識とその学 習. 日本労働雑誌, 474: 39-49.

Lawson, H.A. (1983) Toward a model of teacher socialization in physical education: The subjective warrant, recruitment, and teacher education. Journal of teaching in physical education, 2(3): 3-16.

レナード・スワップ：池村千秋訳（2005）「経験知」を 伝える技術：ディープスマートの本質. ランダムハ ウス講談社 : 東京.

Lortie, D. (1975) Schoolteacher: A sociological study. University of Chicago press: Chicago.

松尾 睦 (2006) 経験からの学習: プロフェッショナ ルの成長プロセス. 同文舘 : 東京.

松尾 睦 (2010) 教師の熟達化と経験学習. 日本語教 育, 144: 26-37.

松尾 睦 (2012) 営業職. 金井·楠見編, 実践知. 有 斐閣 : 東京, pp. 108-120.

三島知剛（2008）教育実習生の実習前後の授業観察力

の変容 : 授業・教師・子どもイメージの関連による

検討. 教育心理学研究, 56: 341-352.

宮下清 (2001) 組織内プロフェッショナル : 新しい組 織と人材のマネジメント. 同友館 : 東京.

Moon, J.A. (2004) A handbook of reflective and experiential learning : Theory and practice. Routledge: London.

中井隆司 (2011) 教師の知識と信念に関する研究の成 果と課題. 日本体育科教育学会編 体育科教育学の 現在. 創文企画 : 東京, pp. 208-222.

Nesper, J. (1987) The role of belief in the practice of teaching. Journal of curriculum studies, 19(4): 317328.

西 穣司 (1990) 教師の教育行為におけるルーティン 化とその生成メカニズム：教師が依拠している知識 に焦点を当てて. 日本学校教育学会編, 学校教育研 究 5 : 学校教育再考. 東信堂: 東京, pp. 72-84.

西田公昭 (1988) 所信の形成と変化の機制についての 研究(1) : 認知的矛盾の解決に及ぼす現実性の効果. 実験社会心理学研究, 28(1): 65 .

西田公昭 (1995) ビリーフの形成と変化の機制につい ての研究(4)：カルト・マインド · コントロールにみ るビリーフ・システムの強化・維持の分析. 社会心 
理学研究, 11(1): 18-29.

西田公昭（1998）信じる心の科学：マインド・コント ロールとビリーフ・システムの社会心理学. サイエ ンス社 : 東京, pp. 23-24.

小塩真司 (2004) SPSS とAmos による心理・調査デー 夕解析. 東京図書 : 東京.

Pajares, F.M. (1992) Teacher's beliefs and educational research: Cleaning up a messy construct. Review of educational research, $62(3)$ : 307-332.

Revegno, I. (2003) Teacher's knowledge construction. In: Silverman, S. and Ennis, C. (Eds.) Student learning in physical education: Applying research to enhance instruction 2nd ed. Human Kinetics: Champaign, pp. 295-310.

Richardson, V. (1996) The role of attitudes and beliefs in learning to teach. In: Sikula, J., Buttery, T., and Guyton, E. (Eds.) Handbook of research on teacher education. Macmillan Library Reference: New York, pp. 102-119.

Rokeach, M. (1960) The open and closed mind. Basic Books: Oxford.

Rokeach, M. (1968) Beliefs, Attitudes and Values: A theory of organization and change. Jossy-Bass: San francisco.

坂本篤史（2007）現職教師は授業経験から如何に学ぶ か. 教育心理学研究, 55(4): 584-556.

沢田和明（2001）体育教師論：体育教師はどのように 作られ, 利用されるか。杉本厚夫編, 体育教育を学 ぶ人のために. 世界思想社 : 京都, pp. 204-219.

Snizek, W.E. (1972) Hall's professionalism: An empirical reassessment. American sociological review, 37 (1) : 109-114.

Sparks, A.C., Templin, T.J., and Schempp, P.G. (1993) Exploring dimensions of marginality: Reflecting on the life histories of physical education teachers. Journal of teaching in physical education, 12 (4) : 386-398.

Stroot, S.A. and Ko, B. (2007) Induction of beginning physical educators into the school setting'. In: Kirk, D.M. and O'sullivan, M. (Eds.) Handbook of Physical Education. Sage: Thousand Oaks, p. 429.

ショーン：佐藤 学・秋田喜代美訳 (2001) 専門家の 知恵: 反省的実践家は行為しながら考える.ゆみる 出版 : 東京.

杉本厚夫（1989）：体育教師の社会学的アンビバラン
ス : 社会的役割に対する認知的不一致. 京都体育学 研究, 4: 1-11.

高井良健一（1994）教職生活に㧍ける中年期の危機. 東京大学教育学部紀要, 34: 323-331.

竹下由紀子 (1996) 授業研究過程での教師の信念の変 容. 新潟大学教育学部紀要 人文. 社会科学編, 37 (2): 259-270.

田尾雅夫（1980）看護婦におけるプロフェッショナリ ズムの態度構造. 病院管理, $17(4): 43-50$.

田尾雅夫（1983）プロフェッショナリズムにおける態 度構造の比較分析. 京都府立大学学術報告「人文」, 35: 159-172.

Tsangaridou, N. (2006) Teacher's beliefs. In: Kirk, D.M. and O'sullivan, M. (Eds.) Handbook of Physical Education. Sage: Thousand Oaks, pp. 486-501.

Tsangaridou, N. (2008) Trainee primary teachers' beliefs and practices about physical education during student teaching. Physical education and sport pedagogy, $13(2)$ : 131-152.

梅野圭史 · 木原成一郎 · 日野克博 · 米村耕平 · 海野勇 三（2010）教師として育つ：体育授業の実践的指導 力を育むには. 明和出版 : 東京, pp. 116-121.

Wang, C.L. and Ha, A.S. (2008) The teacher development in physical education: A review of the literature. Asian social science, 4(12): 3-18.

山㟝準二 (2002) 教師のライフコース研究. 創風社 : 東京, p. 18.

山㟝準二 (2012) 教師のライフコースと発達 · 力量形 成の姿. 山峭準二ほか編, 考える教師：省察, 創 造, 実践する教師. 学文社 : 東京, pp. 98-117.

山下立次 ·徳永敏文 (2000) 中学校運動部活動に関す る調査 : 中学校運動部顧問の没頭度別による分析. 就実女子大学教養課程研究年報, 17: 55-88.

吉崎静夫（1998）一人立ちへの道筋. 浅田匡ほか編, 成長する教師：教師学への誘い. 金子書房 : 東京, pp. 162-173.

善明宣夫（1992）開いた心と閉ざされた心 : ロキーチ の理論を中心に一. 大阪商業大学論集, 94: 91-106.

$$
\left(\begin{array}{l}
\text { 平成 } 25 \text { 年 } 5 \text { 月 } 10 \text { 日受付 } \\
\text { 平成 } 25 \text { 年 } 10 \text { 月 } 25 \text { 日受理 }
\end{array}\right)
$$

Advance Publication by J-STAGE Published online 2014/1/23 